Published in final edited form as:

Neurobiol Dis. 2011 May ; 42(2): 136-147. doi:10.1016/j.nbd.2010.11.015.

\title{
Molecular pathways in dystonia
}

\author{
D. Cristopher Bragg ${ }^{1,2}$, loanna A. Armata ${ }^{1,2}$, Flavia C. Nery ${ }^{1,2}$, Xandra O. Breakefield ${ }^{1,2,3}$, \\ and Nutan Sharma ${ }^{1}$ \\ ${ }^{1}$ Department of Neurology, Massachusetts General Hospital, Charlestown, MA USA \\ ${ }^{2}$ Program in Neuroscience, Harvard Medical School, Boston, MA USA \\ ${ }^{3}$ Department of Radiology, Massachusetts General Hospital, Charlestown, MA USA
}

\begin{abstract}
The hereditary dystonias comprise a set of diseases defined by a common constellation of motor deficits. These disorders are most likely associated with different molecular etiologies, many of which have yet to be elucidated. Here we discuss recent advances in three forms of hereditary dystonia, DYT1, DYT6 and DYT16, which share a similar clinical picture: onset in childhood or adolescence, progressive spread of symptoms with generalized involvement of body regions and a steady state affliction without treatment. Unlike DYT1, the genes responsible for DYT6 and DYT16 have only recently been identified, with relatively little information about the function of the encoded proteins. Nevertheless, recent data suggest that these proteins may fit together within interacting pathways involved in dopaminergic signaling, transcriptional regulation, and cellular stress responses. This review focuses on these molecular pathways, highlighting potential common themes among these dystonias which may serve as areas for future research.
\end{abstract}

\section{Keywords}

Dystonia; torsinA; THAP1; PACT; PRKRA; dopamine; endoplasmic reticulum; transcription; stress

\section{INTRODUCTION}

The dystonias are a heterogenous group of movement disorders in which affected individuals develop sustained, involuntary muscle contractions and twisted postures (Geyer and Bressman, 2006). These deficits may be the sole clinical manifestation or occur as secondary symptoms due to other underlying disease processes, drug/toxin exposure or brain injury (Geyer and Bressman, 2006; Fahn, 1988). Dystonia is generally classified based on somatic distribution of symptoms (focal, segmental, or generalized), age of disease onset (early or late), and etiology (primary or secondary). An alternative scheme, based on Human Genome Organization (HUGO) nomenclature, designates the monogenic dystonias as numbered subtypes, DYT1 - DYT20, according to the order in which clinical features and/ or genetic mapping were first reported. This list of 20 subtypes currently includes (1) pure

\footnotetext{
(C) 2010 Elsevier Inc. All rights reserved.

Correspondence to: Dr. D. C. Bragg Department of Neurology Massachusetts General Hospital Building $149,13^{\text {th }}$ Street Charlestown, MA 02129617.643 .5754 (phone) 617.724 .1537 (facsimile) bragg @ helix.mgh.harvard.edu.

Publisher's Disclaimer: This is a PDF file of an unedited manuscript that has been accepted for publication. As a service to our customers we are providing this early version of the manuscript. The manuscript will undergo copyediting, typesetting, and review of the resulting proof before it is published in its final citable form. Please note that during the production process errors may be discovered which could affect the content, and all legal disclaimers that apply to the journal pertain.
} 
dystonias; (2) dystonia-plus syndromes in which other manifestations, such as parkinsonism or myoclonus, are also present; and (3) paroxysmal dyskinesias, in which dystonia may be an additional feature (de Carvalho Aguiar and Ozelius, 2002; Tanabe et al., 2009; Müller, 2009; Brüggemann and Klein, 2010).

The physiological hallmark of all of these syndromes is the simultaneous contraction of agonist and antagonist muscles, which is believed to reflect a dysfunction in CNS regions controlling movement. The precise nature of this dysfunction is unclear, although a general consensus is that it may involve imbalances in neurotransmission within certain circuits, particularly in the basal ganglia, sensorimotor cortex, brainstem, and cerebellum (for review see Breakefield et al., 2008; Quartarone et al., 2008). How different dystonia-related gene products impact neurotransmission remains unresolved, and it is likely that specific pathogenic mechanisms differ among dystonia subtypes. Nevertheless, studies of dystonia pathogenesis have frequently focused on a few common themes, including neurodevelopmental abnormalities, altered preand/or post-synaptic activity, and neurotoxicity. However, the latter is generally not considered a significant factor in primary dystonia, which is distinguished by a lack of any characteristic neuropathology.

Since primary dystonia constitutes a chronic dysfunction, rather than a neurodegenerative disease, the likelihood is increased that it may eventually be possible to correct the underlying defect(s) once they are fully elucidated. Despite great progress in identifying genetic loci linked to dystonia, it has been difficult to translate that information into a clear understanding of the affected CNS pathways and the functional consequences of specific mutations. Of the 20 current dystonia subtypes, 10 have been linked to mutations in genes encoding novel or previously known proteins (Table 1). In some cases, the effects of the mutations are well understood, as with two genes responsible for DYT5 which encode tyrosine hydroxylase and GTP-cyclohydrolase, both of which are required for dopamine biosynthesis (Segawa, 2000). For other dystonia genes, the function of the encoded proteins and effects of disease mutations are less clear. Understanding how these gene mutations individually culminate in dystonia is obviously critical to designing therapeutic strategies. Yet equally important is the identification of common molecular pathways that may be dysregulated in multiple dystonia subtypes. Given that individual forms of dystonia may be relatively rare, finding common pathways to be targeted for intervention would increase the likelihood that a new treatment approach might have widespread therapeutic benefit.

In this review we discuss recent advances in the biology of three forms of hereditary dystonia: DYT1, DYT6, and DYT16. Compared to DYT1, studies of DYT6 and DYT16 are still in their infancies, with relatively little known about the causative gene products and no animal models yet established for probing disease mechanisms. Yet the limited data that have recently emerged provide initial clues as to potential interactions between these proteins and/or their possible interrelationships to molecular pathways. Here we review these possibilities, highlighting how these proteins may be related to each other in the context of dopamine signaling, transcriptional regulation, and stress responses in the endoplasmic reticulum.

\section{GENES, PROTEINS, AND CLINICAL PHENOTYPES}

As the name implies, the first form of dystonia to be associated with a genetic basis was DYT1, which is caused by a heterozygous, 3-bp deletion that removes one of two adjacent trinucleotides (904_906delGAG/907_909delGAG) in TOR1A (Ozelius et al., 1997). Four other mutations have since been identified in TOR1A (Leung et al., 2001; Kabakci et al., 2004; Zirn et al., 2008, Calakos et al., 2009), although it is unclear whether all are in fact pathogenic (Fig. 1A). The DYT6 gene was recently identified as THAP1, with two 
heterozygous mutations (134_135insGGTGTT; 137_139delAAC and 241T $>$ C) detected in Amish-Mennonite families (Fuchs et al., 2009). Since that discovery, THAP1 mutations have been detected in genetically diverse individuals throughout the world at a rapid pace, with a current count of at least 31 distinct coding mutations in THAP1 which are associated with this form of dystonia (Bressman et al., 2009; Djarmati et al., 2009; Paisan-Ruiz et al., 2009; Bonetti et al., 2009; Xiao et al., 2010; Houlden et al., 2010; Gavarini et al., 2010; Kaiser et al., 2010; Fig. 1B). Most are present in the heterozygous state with one normal copy of the allele, although individuals with mutations in both alleles have been identified (Houlden et al., 2010; N. Sharma, unpublished data). DYT16 appears less prevalent than DYT1 or DYT6 dystonia. Camargos et al. (2008) first described the syndrome in Brazilian families harboring a homozygous mutation $(665 \mathrm{C}>\mathrm{T})$ in $P R K R A$. An additional mutation (266_267delAT) in PRKRA was later reported in one allele of a German patient (Seibler et al., 2008; Fig. 1C).

The sequences and predicted functional domains of the three proteins causing DYT1, DYT6 and DYT16 (Fig. 1) do not reveal obvious relationships among them. The DYT1 protein, torsin $\mathrm{A}$, is a member of the $\mathrm{AAA}^{+}$superfamily of molecular chaperones and one of four mammalian torsins (Ozelius et al., 1997). $\mathrm{AAA}^{+}$proteins typically function as oligomeric complexes, harnessing energy from ATP hydrolysis to drive a diverse range of cellular processes such as protein folding, membrane trafficking, and vesicle fusion (Hanson and Whiteheart, 2005). The pathogenic codon deletion $(\Delta \mathrm{E})$ in torsinA removes a glutamic acid residue from a $\mathrm{C}$-terminal alpha helix believed to be critical for oligomerization and/or tertiary structure (Breakefield et al., 2001; Kock et al., 2006). The DYT6 protein, THAP1 (thanatos-associated [THAP] domain-containing apoptosis-associated protein-1) is an atypical zinc finger protein bearing a large $\mathrm{C} 2 \mathrm{CH}$ module at its amino terminus (Roussigne et al., 2003a). This domain, termed THAP, is a conserved DNA binding module defining a family of over 100 proteins in diverse species, including twelve human THAPs (Roussigne et al., 2003b; Clouaire et al., 2005). THAPs are thought to serve as chromatin-binding factors that regulate transcription, either directly or in complex with other proteins. Most of the known DYT6 mutations impact critical residues in THAP1's DNA binding domain or disrupt its nuclear localization signal, suggesting potential effects on its transcriptional activity (Tamiya et al., 2009). The DYT16 gene encodes the protein, PRKRA (protein kinase, interferon-inducible double stranded RNA dependent activator), also known as PACT (Patel and Sen, 1998). PACT regulates activity of protein kinase R (PKR) via three domains, two (M1 and M2) that bind the kinase and a third (M3) that activates it (Patel et al., 2000; Peters et al., 2001 and 2009). The original DYT16 mutation (P222L) falls within an intermediate spacer between M2 and 3, while the German mutation (H89fsX20) produces a frameshift and possible truncation.

Although the proteins do not share functional domains that reveal immediate connections, the mutations produce overlapping clinical phenotypes. DYT1 and DYT16 are both classified as early-onset dystonias, with symptoms typically appearing before the ages of 28 and 20 years, respectively (Bressman et al., 2000; Camargos et al., 2008). DYT6 onset occurs across a much broader span, ranging from 10 to 80 years. In DYT1 individuals, one or more limbs are typically affected, and the trunk and neck may be affected as well. The arm is the most common site of onset for DYT6, with subsequent spread to craniofacial muscles, leg, and neck (Bressman et al., 2009). A common feature of DYT6 is laryngeal dystonia, producing severe speech defects, which is not often seen in DYT1 (Bressman et al., 2000 and 2009). It should be noted that PRKRA mutations have thus far only been described in two consanguineous families and another isolated case (Camargos et al., 2008; Seibler et al., 2008). Based on these limited observations, it appears that PRKRA mutations produce generalized dystonia, usually beginning in an arm or leg with eventual progression 
to the trunk and neck. As with DYT6, laryngeal dystonia with speech defects may be present (Camargos et al., 2008).

\section{DOPAMINERGIC SIGNALING}

While it is likely that multiple neurotransmitter systems contribute to dystonia pathogenesis in different ways, the pathway most extensively studied to date is dopamine (DA). Multiple lines of evidence suggest that dysfunctions in DA signaling can induce dystonic symptoms (for review, see Wichmann, 2008; Tanabe et al., 2009). In human studies, this hypothesis is supported by reports that dystonia may be associated with: (1) mutations in genes encoding proteins critical for DA biosynthesis, including GTP-cyclohydrolase and tyrosine hydroxylase, as well as polymorphisms in the DA receptor subtype, D5R (Ichinose et al. 1994; Knappskog et al., 1995; Placzek et al., 2001; Misbahuddin et al., 2002); (2) other disease processes affecting DA, of which Parkinson's disease is the best example (Wagner et al., 1996; Tolosa and Compta, 2006); and (3) complications resulting from anti-DA therapies (Katzenschlager et al., 2002; Casey, 2004; Pinninti et al., 2006). Furthermore, early imaging studies detected various DA-related abnormalities, such as altered receptor binding in basal ganglia, in patients with different forms of dystonia (Brashear et al., 1999; Naumann et al., 1998; Perlmutter et al., 1997).

\section{Involvement of torsin A in dopamine neurotransmission}

Soon after the identification of torsinA as the DYT1 protein, initial efforts to map its expression in human brain found particularly high mRNA levels in dopaminergic nigrostriatal neurons (Augood et al., 1998 and 1999). That observation raised questions about a potential function of torsinA in dopaminergic cells and/or role for a DA-related defect in DYT1. Subsequent neurochemical analyses of limited postmortem brain tissue did not clearly resolve these questions. No pathologic lesions were detected in DYT1 in dopaminergic cell bodies in the substantia nigra, or in any other CNS region (Hedreen et al., 1988), although one study reported apparent enlargement of dopaminergic neurons in DYT1 brains relative to controls (Rostasy et al., 2003). Other studies have probed DA neurotransmission indirectly by measuring the total striatal tissue content of DA and its metabolites, mainly 3,4-dihydroxyphenylacetic acid (DOPAC). DA levels in DYT1 striatum appeared either slightly decreased (Furukawa et al., 2000) or roughly equivalent (Augood et al., 2002) to controls, although a significant increase in the DOPAC/DA ratio was detected (Augood et al., 2002) that could suggest enhanced DA turnover. A number of laboratories have since engineered multiple DYT1 mouse models and similarly monitored striatal tissue content of DA and metabolites (Shashidharan et al., 2005; Dang et al., 2005 and 2006; Grundmann et al., 2007; Balcioglu et al., 2007; Zhao et al., 2008; Page et al., 2010). The data have not provided much clarity, with inconsistent results obtained even in the same mouse model when analyzed by separate labs (Balcioglu et al., 2007; Zhao et al., 2008). Taken together, these studies have provided no convincing evidence that DA synthesis is impaired in DYT1, although a recent report describing a specific interaction between torsin A and tyrosine hydroxlase (O'Farrell et al., 2009) indicates this may still be a possibility. In addition, the lack of consistency among striatal DOPAC/DA ratios suggests these measures may lack sufficient sensitivity to reproducibly monitor subtle signaling defects.

To better detect such subtle defects, multiple groups have recently used enhanced analytical techniques to evaluate DA neurotransmission in three different transgenic mouse models in which human wild-type (hWT) or mutant (hMT) torsinA expression was driven by the cytomegalovirus (CMV) promoter (Sharma et al., 2005), the neuron-specific enolase (NSE) promoter (Shashidharan et al., 2005), or the tyrosine hydroxylase (TH) promoter (Page et al., 2010). The CMV and NSE promoters produced widespread transgene expression 
throughout the CNS, whereas the TH promoter allowed selective expression in midbrain dopaminergic neurons (Page et al., 2010). Using in vivo microdialysis, Balcioglu et al. (2007) reported decreased extracellular DA levels following amphetamine exposure in hMT-CMV mice relative to nontransgenic littermates. Amphetamine induces DA release by reversal of the DA transporter (DAT), suggesting a possible DAT dysfunction in DYT1 mice. The hMT-CMV mice also exhibited decreased DA reuptake rates and altered response to a DAT inhibitor, compared to nontransgenic mice (Hewett et al., 2010), suggesting a potential defect in DAT surface expression and/or processing. Other data support this possibility, particularly reports of direct interactions between torsinA and DAT (Torres et al., 2004; Cao et al., 2005) and the vesicular monoamine transporter 2 (VMAT2;

Misbahuddin et al., 2005), which is also important for DA release and turnover.

DA release/reuptake in the NSE and TH mice has been further probed via fast scan cyclic voltammetry, which allows greater temporal resolution (sub-second scale) than microdialysis in monitoring extracellular DA. In both models, lower levels of extracellular DA were detected following evoked release from DYT1 cells vs. controls, but reuptake rates were not compromised (Page et al., 2010; Bao et al., 2010). These observations argue against a DAT dysfunction in these models, pointing instead to impaired DA release. This hypothesis is also supported by other work showing that: (1) torsinA in human brain was detected in presynaptic vesicles (Augood et al., 1999); and (2) in cultured cells torsinA was shown to interact with snapin and participate in vesicular release (Granata et al., 2007). Collectively, studies of all three DYT1 transgenic mice point to a pre-synaptic dysfunction in DA neurons, but additional studies are required to confirm the specific mechanism(s). Given that none of these mice expressed the transgene at high levels, it seems unlikely that the observed defects reflect only nonspecific effects due to overexpressed protein. Nevertheless, it will be useful in future studies to determine the extent to which these defects are also present in DYT1 knock-in mice (Dang et al., 2005).

Postsynaptic defects in DYT1 cells have also been revealed using electrophysiological recordings in striatal slice cultures obtained from the CMV mice and nontransgenic littermates. In hMTCMV derived striatal slices, activation of postsynaptic D2 receptors (D2R) produced aberrant activity, leading to inappropriate firing of cholinergic interneurons (Pisani et al., 2006) and GABAergic medium spiny neurons (Sciamanna et al., 2009). D2Rs, like all DA receptor subtypes, are members of the seven transmembrane G-protein coupled receptor (GPCR) family that exert many of their signaling effects through adenylate cyclase (for review, see Missale et al., 1998). D2R and associated variants are coupled to inhibitory G-proteins $\left(\mathrm{G}_{0 / \mathrm{i}}\right)$ that decrease adenylate cyclase activity, in contrast to D1R and D5R subtypes which act through stimulatory G-proteins (e.g. $\mathrm{G}_{\mathrm{s}} \mathrm{a}$ ) to increase activity. Compared to medium spiny neurons from hWT-CMV and nontransgenic mice, the same cells in hMTCMV mice exhibited decreased surface expression of D2R with inefficient G-protein coupling, despite equivalent levels of D2R mRNA (Napolitano et al., 2010). This observation suggests a potential loss of inhibitory input to adenylate cyclase due to insufficient D2R activity, perhaps resulting from a post-translational defect in receptor processing. Furthermore, the signaling defect in hMT-CMV striatal slices could be rescued by antagonists of adenosine A2A receptors (Napolitano et al., 2010), which provide stimulatory input to adenylate cyclase.

How could post-translational defects in D2R lead to decreased surface expression in DYT1 cells? DA receptors have been shown to oligomerize, forming both homo- and heterocomplexes with other DA receptor subtypes (Agnati et al., 2005a and b; Armstrong and Strange, 2001; Aizman et al., 2000) and even other transmitter receptors, including adenosine A2A, NMDA, and GABA-A (Torvinen et al., 2005; Agnati et al., 2005c). Surface expression of receptors depends on proper oligomerization, which begins in the endoplasmic 
reticulum (ER) and involves molecular chaperones (Balasubramanian et al., 2004; Dunham and Hall, 2009 McLatchie et al., 1998). Examples of ER chaperones which mediate DA receptor trafficking include DRi78 (Bermak et al., 2001) and calnexin (Free et al., 2007), the latter recently confirmed as a binding partner for torsinA (Naismith et al., 2009). TorsinA is localized primarily within the contiguous lumen of the ER and nuclear envelope (NE) and hypothesized to function in this compartment as a molecular chaperone (for review, see Granata et al., 2009; Granata and Warner, 2010). One potential scenario would be that torsinA participates in the proper folding/oligomerization of D2R, either directly or in complex with other chaperones, such as calnexin, and that torsin $A \Delta \mathrm{E}$ impairs this process. Previous data demonstrating a direct interaction between torsinA and D2R support this possibility (Torres et al., 2004).

It should be noted that drugs directly targeting DA receptors have not typically provided significant benefit to patients with DYT1, or most other forms of dystonia. There are probably multiple factors underlying the poor outcomes produced by these drugs, not the least of which is the high frequency of undesirable side effects (Jankovic, 2006). However, if D2R, and possibly other similar receptors, are improperly folded/oligomerized due to a loss of torsinA chaperone activity, then it may not be possible to restore function by using direct pharmacologic ligands to increase or decrease activity. Indeed, the D2R defect in hMT-CMV-derived slice cultures appeared to be two-fold, reflecting not only a decrease in surface receptor expression but also a functional inability to activate the cognate G protein (Napolitano et al., 2010). For that reason, therapeutic strategies may instead have to focus on potential compensatory receptors, such as adenosine A2A (Napolitano et al., 2010), or the downstream targets of DA signaling, such as cholinergic and GABAergic cells. The latter approach forms the basis for most of the current pharmacologic treatments for dystonia, and while it is true that many patients respond to anticholinergic drugs in particular (Jankovic, 2006), the need for better therapies remains clear.

This hypothesized D2R trafficking defect is further supported by recent imaging studies, which used PET with $\left[{ }^{11} \mathrm{C}\right]$-raclopride (RAC) to reveal decreased D2R availability in brains of DYT1 patients relative to controls (Asanuma et al., 2005; Carbon et al., 2009). Significant reductions in radioligand binding were detected in DYT1 caudate, putamen, and ventrolateral thalamus irrespective of clinical disease manifestation, suggesting they may represent carrier traits that form a substratum for development of dystonia when other inducing factors are present (Carbon et al., 2010). Moreover, a particularly striking finding from these investigations is that even greater reductions in D2R availability were apparent in brains of DYT6 patients compared to controls than for the DYT1 patients, independent of clinical disease status (Carbon et al., 2009). These data provide one of the first direct links between DYT6 and a potential DA-related defect, while further suggesting that D2R availability may be a critical factor in both DYT1 and DYT6 dystonias.

\section{Possible role of THAP1 in dopamine neurotransmission}

Unlike the large body of research summarized above for torsinA, no cell biological or biochemical studies have yet examined whether THAP1 has any direct effect on D2R or other aspects of dopamine metabolism. However, indirect observations provide a possible clue. One of the few known binding partners for THAP1 is prostate apoptosis response- 4 (Par-4), a leucine zipper protein that interacts with the C-terminus of THAP1 (Roussigne et al., 2003a). Similar to the THAPs, Par-4 has been shown to promote apoptosis under certain conditions (Sells et al., 1997). Park et al. (2005) recently identified an additional function of Par-4 in neurons, demonstrating that it competed with calmodulin for binding to a cytosolic regulatory domain of $\mathrm{D} 2 \mathrm{R}$ (Fig. 2). Calmodulin is a calcium-dependent, negative regulator of D2R (Bofill-Cardona et al., 2000); in the absence of Par-4, calmodulin binding to D2R decreased receptor activity, thereby removing the inhibitory input to adenylate cyclase (Park 
et al., 2005). These data indicate that a defect in the Par-4:D2R interaction could have the same effect on adenylate cyclase activity as was proposed to occur in DYT1 cells (Napolitano et al., 2010). It is not yet clear whether and how the interaction of THAP1 with Par-4 would affect the ability of Par-4 to bind D2R. Overexpression of THAP1 in cultured cells recruited Par-4 from the cytosol to the nucleus, forming a complex with promyelocytic leukemia (PML) bodies (Roussigne et al., 2003a). It is tempting to speculate that DYT6related changes in THAP1 activity might somehow impact the cytosolic pool of Par-4 available for D2R binding.

Figure 2 presents a potential pathway based on the observations summarized above, emphasizing how activity of D2R could represent one common component of dopaminergic neurotransmission which may be regulated by both torsinA and THAP1. The hypothesized outcome of a D2R defect would be inappropriate postsynaptic activation of adenylate cyclase at dopaminergic synapses due to a loss of inhibitory input from D2R. Based on the results of Napolitano et al. (2010), this overactivity may potentially be rescued by compensatory blockade of adenosine A2A receptors, thereby revealing this receptor class as a possible therapeutic target for dystonia.

\section{TRANSCRIPTIONAL REGULATION}

Although the interaction between THAP1 and Par-4 is intriguing in light of an hypothesized effect on D2R, functional analyses of THAP1 have thus far focused on its role in transcription. The conserved N-terminal THAP domain is a zinc-coordinating module that binds a specific DNA sequence, termed THABS (for THAP DNA-Binding Sequence) (Clouaire et al., 2005). Overexpression and/or silencing of THAP1 in cultured cells altered transcription of a number of genes, including ones known to regulate cell cycle/proliferation (Cayrol et al., 2007). The THABS element was identified within promoters of at least some of these genes, along with evidence that endogenous THAP1 associated with these sequences (Cayrol et al., 2007). These data suggest that THAP1 may modulate transcription, most likely as a repressor, either directly or in complex with other factors such as Par-4 (Roussigne et al., 2003a) or HCF-1 (Mazars et al., 2010). Similar roles in transcription have been suggested for other human THAPs, particularly THAP7 (Macfarlan et al., 2005 and 2006) and THAP11 (Zhu et al., 2009; Dejosez et al., 2010), as well as THAP orthologues in zebrafish (Giangrande et al. 2004) and $C$. elegans (Boxem and van den Heuvel, 2002; Fay et al., 2002). Structural studies of human (Campagne et al., 2010) and Drosophila (Sabogal et al., 2010) THAPs suggest these proteins bind DNA in a bipartite fashion, possibly as dimers.

Most of the currently known DYT6 mutations fall within THAP1's conserved N-terminal domain (Fig. 1B), suggesting potential effects on its ability to bind DNA. An NMR structure for this module was determined, with residues critical for DNA binding identified by sitedirected mutagenesis (Bessiere et al., 2008). By mapping DYT6 mutations onto this model (Fig. 3), it is possible to predict how even single substitutions at certain positions could affect activity. Several DYT6 mutations cluster alongside the zinc ligands, including a substitution at one of the four coordinating residues (C54Y; Gavarini et al., 2010). THABS binding requires zinc and can be inhibited by metal chelators (Clouaire et al., 2005), so mutations at these positions could effectively decrease activity. Other critical sites include: (1) four residues invariant across all known THAPs (P26, W36, F58, P78); (2) a highly conserved C-terminal AVPTIF motif (A76-F81); and (3) three residues (K24, R42, and T48) with exposed basic side chains along with intermediate positions between them (Bessiere et al., 2008). Substitutions at any of these sites were shown to significantly decrease, or completely abolish binding to THABS, and many correspond to sites of known DYT6 mutations. 


\section{Negative regulation of torsinA expression by THAP1}

An intriguing hypothesis linking DYT1 and DYT6 dystonias is that THAP1 may regulate transcription of torsinA, as supported by two recent studies. The human TOR1A promoter has been characterized (Armata et al., 2008) and recently shown to contain two potential binding sites for THAP1: an inverted bipartite motif (-111 bp to $-101 \mathrm{bp}$ from the putative transcriptional start site) and a more upstream, nonconserved motif (-259 bp to -252 bp from the start site; Gavarini et al., 2010; Kaiser et al., 2010). Both studies demonstrated that wildtype THAP1 binds these sequences, whereas multiple DYT6 mutant forms of THAP1 do not. Kaiser et al. (2010) further demonstrated that wild-type THAP1, but not its mutant counterparts, significantly down-regulated TOR1A-driven luciferase expression. That observation suggests that THAP1 may negatively regulate torsinA expression, consistent with the hypothesis that THAP proteins most likely function as transcriptional repressors.

If THAP1 normally represses transcription of torsinA mRNA, then DYT6 mutations which decrease its DNA binding could theoretically lead to abnormally high levels of torsinA protein. This prediction contrasts sharply with the prevailing model of DYT1 pathogenesis, which proposes that the $\Delta \mathrm{E}$ mutation results in a loss of torsin A function (Goodchild et al., 2005; Breakefield et al., 2001). However, in studies of torsinA's role in trafficking of the DA transporter (DAT), overexpression of wild-type torsinA decreased surface expression of DAT, presumably by trapping it within the ER (Torres et al., 2004). In addition, phenotypic abnormalities were observed in transgenic mice overexpressing either human torsin $\mathrm{A} \Delta \mathrm{E}$ or wild-type torsinA, indicating that at high expression levels, the wild-type protein may also interfere with protein processing (Grundmann et al., 2007). A potential hypothesis would then be that torsinA expression levels must be maintained within a certain stoichiometry relative to its binding partners, and that perturbations in either direction might lead to imbalances that cause dysfunction. Whether this hypothesis may account for any of the cellular defects underlying DYT6 pathogenesis remains to be determined.

\section{Torsin A and the nuclear envelope}

While torsinA does not appear to play a direct role itself in transcription, it has been clearly linked to the integrity of the nuclear envelope (NE; Goodchild and Dauer, 2004; GonzalezAlegre and Paulson, 2004; Bragg et al., 2004a; Naismith et al., 2004; Goodchild et al., 2005; Giles et al., 2008; Nery et al., 2008). Given evidence that nuclear pore complexes and related lamin proteins may influence gene regulation (for review, see Kohler and Hurt, 2010; Kalverda et al., 2010; Andres and Gonzalez, 2009), it is possible that torsinA function within the NE could ultimately impact gene expression. Efforts to characterize DYT1related molecular signatures in cultured cells (Baptista et al., 2003; Martin et al., 2009) or mouse models (Grundmann et al., 2008) have detected only modest transcriptional changes. However, recent profiling in blood of DYT1 individuals relative to controls revealed a signature that appeared to correlate with clinical disease penetrance (Walter et al. 2010).

In mice, homozygous knockout of wild-type torsin $\mathrm{A}$ or knock-in of the $\Delta \mathrm{E}$ mutation resulted in NE structural defects which were only found in neurons (Goodchild et al., 2005). A potential basis for this cell-type specificity has recently been attributed to torsinB, which appeared to compensate for loss of torsinA activity in non-neuronal cells which have higher levels of torsinB than do most neurons (Kim et al., 2010). These results provide a possible explanation for the neurologic specificity of the DYT1 clinical phenotype, despite widespread cellular distribution of torsinA, while also revealing torsinB as a potential therapeutic target. 


\section{ENDOPLASMIC RETICULUM STRESS}

Given that the bulk of torsinA appears to reside within the ER lumen, numerous studies have attempted to define its role and/or a functional consequence of torsin $\mathrm{A} \triangle \mathrm{E}$ in this compartment. Although multiple theories have been advanced, they can be distilled into three, non-mutually exclusive hypotheses: (1) torsin $\mathrm{A} \Delta \mathrm{E}$ is a misfolded protein which triggers an ER stress response; (2) torsin A acts as a classical chaperone, assisting in the folding of client proteins that move through the secretory pathway; and (3) torsinA functions in modulating the response of cells to ER stress induced by misfolded proteins (Fig. 4).

\section{Torsin $\mathrm{A} \Delta \mathrm{E}$ as a direct trigger for $\mathrm{ER}$ stress}

Studies addressing the possibility that torsinA directly induces ER stress have produced inconsistent findings. Initial biophysical analyses detected no significant differences between wild-type torsin $\mathrm{A}$ and torsin $\mathrm{A} \Delta \mathrm{E}$ to suggest that the missing glutamic acid would result in gross protein misfolding (Kustedjo et al., 2003). More recent comparisons reported that torsin $\mathrm{A}$ and torsin $\mathrm{A} \triangle \mathrm{E}$ were processed by different degradation pathways, with the mutant protein selectively targeted for destruction by the proteosome (Gordon and Gonzalez-Alegre, 2008; Giles et al., 2008 and 2009). That observation suggests that torsin $\mathrm{A} \Delta \mathrm{E}$ displays unique structural features that not only distinguish it from the wild-type protein but also selectively trigger the proteosomal pathway. In cultured cells, overexpression of torsin $\mathrm{A} \Delta \mathrm{E}$ at high levels produced aberrant NE/ER-derived membrane whorls (Hewett et al., 2000; Kustedjo et al., 2000; Bragg et al., 2004b), which have been shown to form upon activation of the unfolded protein response (UPR; Cox et al., 1997; Snapp et al 2003). Yet overexpression of torsin $A \Delta E$ was not accompanied by increased levels of the UPR regulator, BiP (Bragg et al., 2004c), nor was increased BiP expression detected in DYT1 patient fibroblasts relative to controls (Hewett et al., 2008). However, in transgenic $C$. elegans, nematodes overexpressing human torsin $\mathrm{A} \Delta \mathrm{E}$, but not torsin $\mathrm{A}$, showed increased expression of a BiP reporter construct, indicating UPR activation (Chen et al., 2010).

\section{TorsinA as an ER chaperone}

The prospect that torsinA functions as a molecular chaperone within the ER/secretory pathway has been supported by studies using luminescent reporters to measure secretion from cells in which torsin $\mathrm{A} / \Delta \mathrm{E}$ levels were manipulated. The results revealed secretion defects in (1) DYT1 patient fibroblasts (Hewett et al., 2007); (2) control human fibroblasts in which torsinA expression has been silenced (Hewett et al., 2008); and (3) murine embryonic fibroblasts (MEFs) from torsinA knock-out mice (Hewett et al., 2007). In addition, overexpression of wild-type torsin A in CHO cells enhanced secretion of multiple reporter proteins (Josse et al., 2010), and the secretion defect in DYT1 patient cells could be rescued by selective knock-down of torsin $\mathrm{A} \Delta \mathrm{E}$ or upregulation of torsin $\mathrm{A}$, but not of torsinB (Hewett et al., 2008). However, direct measurement of torsinA chaperone behavior in a cell-free system revealed no differences between the wild-type and mutant proteins (Burdette et al., 2010), suggesting that the secretion defect may not simply be explained by a general failure of torsin $\mathrm{A} \Delta \mathrm{E}$ to fold target proteins.

Another potential explanation for the apparent secretion defect in DYT1 fibroblasts is that it reflected a chronic, low level of ER stress even though BiP levels were not obviously increased relative to controls. The response to ER stress generally involves three main components (for review, see Boyce and Yuan, 2006): (1) transient downregulation of protein translation to reduce traffic through the ER, induced by phosphorylation of eukaryotic translation initiation factor 2 subunit a (eIF2a) primarily by protein kinase R-like ER kinase (PERK); (2) increased expression of ER chaperone proteins, induced by the generation of 
transcription factors, XBP-1 and ATF6; and (3) retrotranslocation of misfolded proteins via the ER-Associated Degradation (ERAD) pathway for destruction by the proteosome (Fig. 4). In $C$. elegans, transgenic nematodes overexpressing human torsinA, but not torsin $\mathrm{A} \Delta \mathrm{E}$, appeared resistant to pharmacologic induction of ER stress, indicating that torsinA may serve as a buffer against stressful stimuli (Chen et al., 2010). Furthermore, DYT1 patient fibroblasts are more sensitive to ER stress-inducing agents than control fibroblasts (Nery, Armata et al., in preparation), suggesting they may lack this buffering capacity. These data indicate that torsinA may function at some level within the broad ER stress response; if not as a classic chaperone, then perhaps as a release valve acting in concert with other ER sensors. A potential loss of that function by torsin $\mathrm{A} \Delta \mathrm{E}$ could indirectly lead to a chronic, low level activation of ER stress by impairing the cell's ability to properly clear misfolded proteins. A failure of protein quality control systems is believed to underlie other neurologic diseases, although these largely represent late-onset, degenerative disorders involving significant neuronal cell death, unlike DYT1 (Paschen and Frandsen, 2001). Nevertheless, a consolidation of current findings would suggest that the presence of torsin $\mathrm{A} \Delta \mathrm{E}$ somehow contributes to ER stress load, either directly or indirectly, although the precise nature of this phenomenon has yet to be elucidated.

\section{Potential involvement of PACT and THAP proteins in the ER stress response}

The significance of this ER stress pathway for dystonia is further illustrated by studies on the DYT16 protein, PACT. PACT is a double stranded RNA (dsRNA) binding protein which serves primarily to regulate activity of the cytosolic kinase, protein kinase R (PKR) (Patel and Sen, 1998; Patel et al., 2000). Different stress stimuli induce PACT to activate PKR, resulting in phosphorylation of eIF2a (Patel et al., 2000; Peters et al., 2001; Huang et al., 2002), analogous to signaling via the ER stress-related kinase, PERK (Boyce and Yuan, 2006). Indeed, PKR and PERK share functional similarities, converging on eIF2a to decrease global protein synthesis as a protective measure against different toxic insults (for review, see Raven and Koromilas, 2008). Initial studies described PACT/PKR induction in response to mainly cytosolic stimuli (Patel et al., 2000). However, recent investigations reported that PACT was also upregulated during ER stress signaling and that the downstream phosphorylation of eIF2a during ER stress was mediated to some extent by PACT/PKR functioning independently of PERK (Lee et al., 2007). Although no study has yet directly evaluated the functional effects of dystonia-related mutations in PACT on stressrelated responses, examination of the protein's modular structure allows some predictions. PACT contains three modular domains, the first two which mediate binding to PKR while the third mediates PKR activation (Peters et al., 2001 and 2009). Mutations that disrupt the third domain allow binding to PKR, but convert PACT into a PKR inhibitor, preventing phosphorylation of eIF2a (Huang et al., 2002). The homozygous DYT16 mutation, P222L (Camargos et al., 2008), falls in an intermediate region at the border of the third domain (Fig. 1), and it is unclear what structural impact it may have on PACT. The German mutation, H89fsX20 (Seibler et al., 2008) occurs in the first domain and is predicted to truncate the protein, potentially removing the third domain. Thus one hypothesis is that these mutants interfere with PACT activation of PKR and subsequent phosphorylation of eIF2a, thereby disrupting the cellular response to cytosolic and/or ER stress and making DTY16 cells more susceptible to stress conditions.

Other noteworthy features of this stress pathway are two additional upstream regulators of PKR. p58IPK is a cellular PKR inhibitor that balances the kinase's activity in concert with PACT (Lee et al., 1994). This inhibitory input is removed by interactions between p58IPK and another protein, previously designated p52rIPK or PRKRIR (protein-kinase, interferoninducible double stranded RNA dependent inhibitor, repressor of [P58 repressor]; Gale et al., 1998). Following the initial cloning of THAP1 and identification of its protein family, it 
was recognized that PRKRIR contains a conserved N-terminal THAP domain and would properly be designated THAP0 (Roussigne et al., 2003b). THAP0 thus exerts a similar positive effect on PKR as does PACT, albeit indirectly by binding p58IPK and preventing its inhibitory effects. There are currently no data directly implicating THAP1 in the p58IPK/ PKR pathway. However, the THAPs bear highly similar structural domains and are hypothesized to dimerize, thus it is possible that future studies may eventually uncover an interaction that places THAP1 at some level in the PKR pathway with its close relative, THAPO.

\section{PACT, torsinA, and oxidative stress}

In addition to their possible roles in ER stress responses, both PACT and torsinA have been potentially linked to oxidative stress signaling, albeit in different ways. In cultured cells, peroxide exposure resulted in rapid phosphorylation of PACT and an increased association with PKR (Patel et al., 2000). TorsinA may also be modified during oxidative stress, with a subsequent decrease in its ability to bind LAP1 and LULL1 (Hewett et al., 2003; Zhu et al., 2010). Previous studies have demonstrated that the interaction between torsin $A$ and either LAP1 and LULL1 is dependent on nucleotide binding and destabilized by the $\triangle \mathrm{E}$ deletion (Naismith et al., 2009). The results of Zhu et al. (2010) further suggest that redox status may also influence torsin $\mathrm{A}$ binding activity and that the $\Delta \mathrm{E}$ deletion may inhibit a redoxdependent change in the conformation of the carboxy terminus.

This relationship between torsinA and cellular redox status could be reciprocal, given reports that torsinA somehow buffers cells from oxidative insults (Kuner et al., 2003; Shashidharan et al., 2004; Chen et al., 2010). In contrast, overexpression of PACT greatly enhanced apoptosis in cells treated with peroxide (Patel et al., 2000). These data suggest that PACT and torsinA may serve different roles in the cellular response to oxidative stress, and it is currently unclear how either of these roles may be affected by their respective mutations. Nevertheless, a possible relationship between oxidative stress and dystonia is further supported by reports that dystonic symptoms are a common feature of mitochondrial disorders in which cellular redox status is altered (Naviaux, 2000; Finsterer, 2008). Thus understanding how torsin A and PACT function in this cascade could ultimately offer insight into possible disease mechanisms.

Figure 4 outlines a signal transduction pathway coordinating responses to ER and/or cellular stresses. As with D2R discussed above, PKR, PERK, and eIF2a may represent potential points of convergence for the DYT1, DYT16, and possibly DYT6 proteins. Given the particularly broad and interactive nature of this signaling response, considerable effort is needed to clearly delineate functional roles for these proteins and identify specific relationships between them.

\section{SEEKING COMMON THEMES IN DYSTONIA NEUROBIOLOGY}

Translational research in the dystonias has generally lagged behind efforts for other neurologic diseases for multiple reasons. Although collectively the dystonias represent a common movement disorder, estimated as the third most prevalent behind Parkinson's disease and essential tremor, individual forms of dystonia, particularly the monogenic ones, are relatively rare and probably caused by different molecular etiologies. In most cases, these etiologies are poorly understood, thereby limiting efforts to design functional assays that could be used to screen for novel therapeutics. Fortunately, for DYT1 at least, more than a decade of cell biology is now beginning to give rise to chemical biology, with reports describing new screening approaches (Dorval et al., 2010) and the first small molecule modulator of a torsinA-related cellular phenotype (Cao et al., 2010). For most of the other monogenic dystonias, more work is needed to understand the gene products before 
translational projects can realistically be undertaken. Within that context, the identification of functional pathways impacted by multiple dystonia genes should be considered a particular priority. If such pathways exist, as they appear, they may represent the best potential targets for therapeutic intervention which could eventually offer widespread benefit to a broad and diverse population of dystonia patients.

\section{Acknowledgments}

The authors gratefully acknowledge Dr. John R. Engen, for assistance with structural modeling of THAP1, Ms. Emily Mills and Millstone Design (www.millstone.com) for preparation of Figures 2 and 4, and Ms. Suzanne McDavitt, for skilled editorial assistance with this manuscript. This work supported by NIH/NINDS grants NS064450 (DCB), NS069973 (DCB), NS037409 (XOB, NS), as well as grants from Tyler's Hope for a Dystonia Cure, Inc. (DCB) and the Dystonia Medical Research Foundation (FCN).

\section{ABBREVIATIONS}

D2R

DA

DAT

DOPAC

eIF2a

ER

ERAD

GABA-A

GPCR

GTP

hMT

hWT

NE

NMDA

p58IPK

p58rIPK

PACT

PERK

PKR

PML

PRKRA

PRKRIR

THABS

THAP1

UPR dopamine receptor subtype 2

dopamine

dopamine transporter

3,4-dihydroxyphenylacetic acid

eukaryotic translation initiation factor subunit 2 alpha

endoplasmic reticulum

endoplasmic reticulum associated degradation

gamma amino butyric acid-A

G-protein coupled receptor

guanosine triphosphate

transgenic mice expressing human torsin $\mathrm{A} \Delta \mathrm{E}$

transgenic mice expressing human wild-type torsinA

nuclear envelope

$\mathrm{N}$-methyl-D-aspartate

inhibitor of protein kinase $\mathrm{R}$

repressor of p58IPK

protein activator of protein kinase $\mathrm{R}$

protein kinase R-like ER kinase

protein kinase $\mathrm{R}$

promyelocytic leukemia

protein kinase, interferon-inducible double stranded RNA dependent activator

protein-kinase, interferon-inducible double stranded RNA dependent inhibitor, repressor of (P58 repressor)RAC, raclopride

THAP1 DNA binding sequence

thanatos-associated [THAP] domain-containing apoptosis-associated protein-1

unfolded protein response 
VMAT2 vesicular monoamine transporter 2

\section{References}

Agnati LF, Ferre SB, R. Woods A, Genedani S, Franco R, Fuxe K. Existence and theoretical aspects of homomeric and heteromeric dopamine receptor complexes and their relevance for neurological diseases. Neuromolecular Med. 2005a; 7:61-78. [PubMed: 16052039]

Agnati LF, Fuxe K, Ferré S. How receptor mosaics decode transmitter signals. Possible relevance of cooperativity. Trends Biochem Sci. 2005b; 30:188-193. [PubMed: 15817395]

Agnati LF, Tarakanov AO, Ferré S, Fuxe K, Guidolin D. Receptor-receptor interactions, receptor mosaics, and basic principles of molecular network organization: possible implications for drug development. J Mol Neurosci. 2005c; 26:193-208. [PubMed: 16012193]

Aizman O, Brismar H, Uhlén P, Zettergren E, Levey AI, Forssberg H, Greengard P, Aperia A. Anatomical and physiological evidence for D1 and D2 dopamine receptor colocalization in neostriatal neurons. Nat Neurosci. 2000; 3:226-230. [PubMed: 10700253]

Andrés V, González JM. Role of A-type lamins in signaling, transcription, and chromatin organization. J Cell Biol. 2009; 187:945-957. [PubMed: 20038676]

Armata IA, Ananthanarayanan M, Balasubramaniyan N, Shashidharan P. Regulation of DYT1 gene expression by the Ets family of transcription factors. J Neurochem. 2008; 106:1052-1065. [PubMed: 18466338]

Armstrong D, Strange PG. Dopamine D2 receptor dimer formation: evidence from ligand binding. J Biol Chem. 2001; 276:22621-22629. [PubMed: 11278324]

Asanuma K, Carbon-Correll M, Eidelberg D. Neuroimaging in human dystonia. J Med Invest. 2005; 52:272-279. [PubMed: 16366514]

Augood SJ, Hollingsworth Z, Albers DS, Yang L, Leung JC, Muller B, Klein C, Breakefield XO, Standaert DG. Dopamine transmission in DYT1 dystonia: a biochemical and autoradiographical study. Neurology. 2002; 59:445-458. [PubMed: 12177384]

Augood SJ, Martin DM, Ozelius LJ, Breakefield XO, Penney JB Jr. Standaert DG. Distribution of the mRNAs encoding torsinA and torsinB in the normal adult human brain. Ann Neurol. 1999; 46:761-769. [PubMed: 10553994]

Augood SJ, Penney JB Jr. Friberg IK, Breakefield XO, Young AB, Ozelius LJ, Standaert DG. Expression of the early-onset torsion dystonia gene (DYT1) in human brain. Ann Neurol. 1998; 43:669-673. [PubMed: 9585364]

Balasubramanian S, Teissére JA, Raju DV, Hall RA. Hetero-oligomerization between GABAA and GABAB receptors regulates GABAB receptor trafficking. J Biol Chem. 2004; 279:18840-18850. [PubMed: 14966130]

Balcioglu A, Kim M-O, Sharma N, Cha J-H, Breakefield XO, Standaert DG. Dopamine release is impaired in a mouse model of DYT1 dystonia. J Neurochem. 2007; 102:783-788. [PubMed: 17550429]

Bao L, Patel JC, Walker RH, Shashidharan P, Rice ME. Dysregulation of striatal dopamine release in a mouse model of dystonia. J Neurochem. 2010 Epub ahead of print.

Baptista MJ, O'Farrell C, Hardy J, Cookson MR. Microarray analysis reveals induction of heat shock proteins mRNAs by the torsion dystonia protein, TorsinA. Neurosci Lett. 2003; 343:5-8. [PubMed: 12749984]

Bermak JC, Li M, Bullock C, Zhou QY. Regulation of transport of the dopamine D1 receptor by a new membrane-associated ER protein. Nat Cell Biol. 2001; 3:492-498. [PubMed: 11331877]

Bessière D, Lacroix C, Campagne S, Ecochard V, Guillet V, Mourey L, Lopez F, Czaplicki J, Demange P, Milon A, Girard JP, Gervais V. Structure-function analysis of the THAP zinc finger of THAP1, a large C2CH DNA-binding module linked to Rb/E2F pathways. J Biol Chem. 2008; 283:4352-4363. [PubMed: 18073205]

Bofill-Cardona E, Kudlacek O, Yang Q, Ahorn H, Freissmuth M, Nanoff C. Binding of calmodulin to the D2-dopamine receptor reduces receptor signaling by arresting the $\mathrm{G}$ protein activation switch. J Biol Chem. 2000; 275:32672-32680. [PubMed: 10926927] 
Bonetti M, Barzaghi C, Brancati F, Ferraris A, Bellacchio E, Giovanetti A, Ialongo T, Zorzi G, Piano C, Petracca M, Albanese A, Nardocci N, Dallapiccola B, Bentivoglio AR, Garavaglia B, Valente EM. Mutation screening of the DYT6/THAP1 gene in Italy. Mov Disord. 2009; 24:2424-2427. [PubMed: 19908325]

Boxem M, van den Heuvel S. C. elegans class B synthetic multivulva genes act in G(1) regulation. Curr Biol. 2002; 12:906-911. [PubMed: 12062054]

Boyce M, Yuan J. Cellular response to endoplasmic reticulum stress: a matter of life or death. Cell Death Differ. 2006; 13:363-373. [PubMed: 16397583]

Bragg DC, Camp SM, Kaufman CA, Wilbur JD, Boston H, Schuback DE, Hanson PI, Sena-Esteves M, Breakefield XO. Perinuclear biogenesis of mutant torsin-A inclusions in cultured cells infected with tetracycline-regulated herpes simplex virus type 1 amplicon vectors. Neuroscience. 2004a; 125:651-661. [PubMed: 15099679]

Bragg DC, Slater DJ, Breakefield XO. TorsinA and early-onset torsion dystonia. Adv Neurol. 2004b; 94:87-93. [PubMed: 14509659]

Bragg DC, Kaufman CA, Kock N, Breakefield XO. Inhibition of N-linked glycosylation prevents inclusion formation by the dystonia-related mutant form of torsinA. Mol Cell Neurosci. 2004c; 27:417-426. [PubMed: 15555920]

Brashear A, Mulholland GK, Zheng QH, Farlow MR, Siemers ER, Hutchins GD. PET imaging of the pre-synaptic dopamine uptake sites in rapid-onset dystoniaparkinsonism (RDP). Mov Disord. 1999; 14:132-137. [PubMed: 9918356]

Breakefield XO, Blood AJ, Li Y, Hallett M, Hanson PI, Standaert DG. The pathophysiologic basis of the dystonias. Nat Rev Neurosci. 2008; 9:222-234. [PubMed: 18285800]

Breakefield XO, Kamm C, Hanson PI. TorsinA: movement at many levels. Neuron. 2001; 31:9-12. [PubMed: 11498045]

Bressman SB, Raymond D, Fuchs T, Heiman GA, Ozelius LJ, Saunders-Pullman R. Mutations in THAP1 (DYT6) in early-onset dystonia: a genetic screening study. Lancet Neurol. 2009; 8:441446. [PubMed: 19345147]

Bressman SB, Sabatti C, Raymond D, de Leon D, Klein C, Kramer PL, Brin MF, Fahn S, Breakefield X, Ozelius LJ, Risch NJ. The DYT1 phenotype and guidelines for diagnostic testing. Neurology. 2000; 54:1746-1752. [PubMed: 10802779]

Brüggemann N, Klein C. Genetics of primary torsion dystonia. Curr Neurol Neurosci Rep. 2010; 10:199-206. [PubMed: 20425035]

Burdette AJ, Churchill PF, Caldwell GA, Caldwell KA. The early-onset torsion dystonia-associated protein, torsinA, displays molecular chaperone activity in vitro. Cell Stress Chaperones. 2010 Epub ahead of print.

Calakos N, Patel V, Gottron M, Wang G, Tran-Viet KN, Brewington D, Beyer JL, Steffens DC, Krishnan RR, Zuchner S. Functional evidence implicating a novel TOR1A mutation in idiopathic, late-onset focal dystonia. J Med Genet. 2010 Epub ahead of print.

Camargos S, Scholz S, Simón-Sánchez J, Paisán-Ruiz C, Lewis P, Hernandez D, Ding J, Gibbs JR, Cookson MR, Bras J, Guerreiro R, Oliveira CR, Lees A, Hardy J, Cardoso F, Singleton AB. DYT16, a novel young-onset dystonia-parkinsonism disorder: identification of a segregating mutation in the stress-response protein PRKRA. Lancet Neurol. 2008; 7:207-215. [PubMed: 18243799]

Campagne S, Saurel O, Gervais V, Milon A. Structural determinants of specific DNA-recognition by the THAP zinc finger. Nucleic Acids Res. 2010; 38:3466-3476. [PubMed: 20144952]

Cao S, Gelwix CC, Caldwell KA, Caldwell GA. Torsin-mediated protection from cellular stress in the dopaminergic neurons of Caenorhabditis elegans. J Neurosci. 2005; 25:3801-3812. [PubMed: 15829632]

Cao S, Hewett JW, Yokoi F, Lu J, Buckely AC, Burdette AJ, Chen P, Nery FC, Li Y, Breakefield XO, Caldwell GA, Caldwell KA. Chemical enhancement of torsinA function in cell and animal models of torsion dystonia. Dis Models Mech. 2010; 3:386-396.

Carbon M, Argyelan M, Eidelberg D. Functional imaging in hereditary dystonia. Eur J Neurol. 2010; (Suppl 1):58-64. [PubMed: 20590810] 
Carbon M, Niethammer M, Peng S, Raymond D, Dhawan V, Chaly T, Ma Y, Bressman S, Eidelberg D. Abnormal striatal and thalamic dopamine neurotransmission: Genotype-related features of dystonia. Neurology. 2009; 72:2097-2103. [PubMed: 19528516]

Casey DE. Pathophysiology of antipsychotic drug-induced movement disorders. J Clin Psychiatry. 2004; 65:25-28. [PubMed: 15189109]

Cayrol C, Lacroix C, Mathe C, Ecochard V, Ceribelli M, Loreau E, Lazar V, Dessen P, Mantovani R, Aguilar L, Girard JP. The THAP-zinc finger protein THAP1 regulates endothelial cell proliferation through modulation of pRB/E2F cell-cycle target genes. Blood. 2007; 109:584-594. [PubMed: 17003378]

Chen P, Burdette AJ, Porter CJ, Ricketts JC, Fox SA, Hewett JW, Nery FC, Berkowitz LA, Breakefield XO, Caldwell KA, Caldwell GA. The early-onset torsion dystonia associated protein, torsin A, is a homeostatic regulator of endoplasmic reticulum stress response. Hum Mol Genet. 2010; 19(18):3502-18. [PubMed: 20584926]

Chen XP, Hu XH, Wu SH, Zhang YW, Xiao B, Shang HF. RNA interference-mediated inhibition of wild-type Torsin A expression increases apoptosis caused by oxidative stress in cultured cells. Neurochem. Res. 2010; 35(8):1214-23. [PubMed: 20455020]

Clouaire T, Roussigne M, Ecochard V, Mathe C, Amalric F, Girard JP. The THAP domain of THAP1 is a large $\mathrm{C} 2 \mathrm{CH}$ module with zinc-dependent sequence-specific DNA-binding activity. Proc Natl Acad Sci U S A. 2005; 102:6907-6912. [PubMed: 15863623]

Cox JS, Chapman RE, Walter P. The unfolded protein response coordinates the production of endoplasmic reticulum protein and endoplasmic reticulum membrane. Mol Biol Cell. 1997; 8:1805-1814. [PubMed: 9307975]

Dang MT, Yokoi F, McNaught KS, Jengelley TA, Jackson T, Li J, Li Y. Generation and characterization of Dyt1 DeltaGAG knock-in mouse as a model for early-onset dystonia. Exp Neurol. 2005; 196:452-463. [PubMed: 16242683]

Dang MT, Yokoi F, Pence MA, Li Y. Motor deficits and hyperactivity in Dyt1 knockdown mice. Neurosci Res. 2006; 56:470-474. [PubMed: 17046090]

de Carvalho Aguiar PM, Ozelius LJ. Classification and genetics of dystonia. Lancet Neurol. 2002; 1:316-325. [PubMed: 12849429]

Dejosez M, Levine SS, Frampton GM, Whyte WA, Stratton SA, Barton MC, Gunaratne PH, Young RA, Zwaka TP. Ronin/Hcf-1 binds to a hyperconserved enhancer element and regulates genes involved in the growth of embryonic stem cells. Genes Dev. 2010; 24:1479-1484. [PubMed: 20581084]

Djarmati A, Schneider SA, Lohmann K, Winkler S, Pawlack H, Hagenah J, Brüggemann N, Zittel S, Fuchs T, Raković A, Schmidt A, Jabusch HC, Wilcox R, Kostić VS, Siebner H, Altenmüller E, Münchau A, Ozelius LJ, Klein C. Mutations in THAP1 (DYT6) and generalised dystonia with prominent spasmodic dysphonia: a genetic screening study. Lancet Neurol. 2009; 8:447-452. [PubMed: 19345148]

Dorval T, Ogier A, Genovesio A, Lim HK, Kwon DY, Lee JH, Worman HJ, Dauer W, Grailhe R. Contextual Automated 3D Analysis of Subcellular Organelles Adapted to High-Content Screening. J Biomol Screen. 2010 Epub ahead of print.

Dunham JH, Hall RA. Enhancement of the surface expression of G protein-coupled receptors. Trends Biotechnol. 2009; 27:541-545. [PubMed: 19679364]

Fahn S. Concept and classification of dystonia. Adv Neurol. 1988; 50:1-8. [PubMed: 3041755]

Fay DS, Keenan S, Han M. fzr-1 and lin-35/Rb function redundantly to control cell proliferation in C. elegans as revealed by a nonbiased synthetic screen. Genes Dev. 2002; 16:503-517. [PubMed: 11850412]

Finsterer J. Leigh and Leigh-like syndrome in children and adults. Pediatr. Neurol. 2008; 39(4):22335. [PubMed: 18805359]

Free RB, Hazelwood LA, Cabrera DM, Spalding HN, Namkung Y, Rankin ML, Sibley DR. D1 and D2 dopamine receptor expression is regulated by direct interaction with the chaperone protein calnexin. J Biol Chem. 2007; 282:21285-21300. [PubMed: 17395585] 
Fuchs T, Gavarini S, Saunders-Pullman R, Raymond D, Ehrlich ME, Bressman SB, Ozelius LJ. Mutations in the THAP1 gene are responsible for DYT6 primary torsion dystonia. Nat Genet. 2009; 41:286-288. [PubMed: 19182804]

Furukawa Y, Hornykiewicz O, Fahn S, Kish SJ. Striatal dopamine in early-onset primary torsion dystonia with the DYT1 mutation. Neurology. 2000; 54:1193-1195. [PubMed: 10720299]

Gale MJ, Blakely CM, Hopkins DA, Melville MW, Wambach M, Romano PR, Katze MG. Regulation of interferon-induced protein kinase PKR: modulation of P58IPK inhibitory function by a novel protein, P52rIPK. Mol Cell Biol. 1998; 18

Gavarini S, Cayrol C, Fuchs T, Lyons N, Ehrlich ME, Girard J-P, Ozelius LJ. A direct interaction between causative genes of DYT1 and DYT6 primary dystonia. Ann Neurol. 2010; 68(4):549-53. [PubMed: 20865765]

Geyer HL, Bressman SB. The diagnosis of dystonia. Lancet Neurol. 2006; 5:780-790. [PubMed: 16914406]

Giangrande PH, Zhu W, Schlisio S, Sun X, Mori S, Gaubatz S, Nevins JR. A role for E2F6 in distinguishing G1/S- and G2/M-specific transcription. Genes Dev. 2004; 18:2941-2951. [PubMed: 15574595]

Giles LM, Chen J, Li L, Chin LS. Dystonia-associated mutations cause premature degradation of torsinA protein and cell-type-specific mislocalization to the nuclear envelope. Hum Mol Genet. 2008; 17:2712-2722. [PubMed: 18552369]

Giles LM, Li L, Chin LS. TorsinA protein degradation and autophagy in DYT1 dystonia. Autophagy. 2009; 5:82-84. [PubMed: 18971629]

Gonzalez-Alegre P, Paulson HL. Aberrant cellular behavior of mutant torsinA implicates nuclear envelope dysfunction in DYT1 dystonia. J Neurosci. 2004; 24:2593-2601. [PubMed: 15028751]

Goodchild RE, Dauer WT. Mislocalization to the nuclear envelope: an effect of the dystonia-causing torsinA mutation. Proc Natl Acad Sci U S A. 2004; 101:847-852. [PubMed: 14711988]

Goodchild RE, Kim CE, Dauer WT. Loss of the dystonia-associated protein torsinA selectively disrupts the neuronal nuclear envelope. Neuron. 2005; 48:923-932. [PubMed: 16364897]

Gordon KL, Gonzalez-Alegre P. Consequences of the DYT1 mutation on torsinA oligomerization and degradation. Neurosci. 2008; 157:588-595.

Granata A, Schiavo G, Warner TT. Torsin A and dystonia: from nuclear envelope to synapse. J Neurochem. 2009; 109:1596-1609. [PubMed: 19457118]

Granata A, Warner TT. The role of torsinA in dystonia. Eur J Neurol. 2010; (Suppl 1):81-87. [PubMed: 20590813]

Granata A, Watson R, Collinson LM, Schiavo G, Warner TT. The dystonia-associated protein torsina modulates synaptic vesicle recycling. J Biol Chem. 2007

Grundmann K, Reischmann B, Vanhoutte G, Hubener J, Teismann P, Hauser TK, Bonin M, Wilbertz J, Horn S, Nguyen HP, Kuhn M, Chanarat S, Wolburg H, Van der Linden A, Riess O. Overexpression of human wildtype torsinA and human DeltaGAG torsinA in a transgenic mouse model causes phenotypic abnormalities. Neurobiol Dis. 2007; 27:190-206. [PubMed: 17601741]

Grundmann K, Hubener J, Habig K, Reischmann B, Poths S, Hauser TK, Magg J, Riess O, Bonin M, Nguyen HP. Gene expression changes in a transgenic mouse model overexpressing human wildtype and mutant torsinA. Proteomics Clin. Appl. 2008; 2(5):720-736. [PubMed: 21136869]

Hanson PI, Whiteheart SW. AAA+ proteins: have engine, will work. Nat Rev Mol Cell Biol. 2005; 6:519-529. [PubMed: 16072036]

Hedreen JC, Zweig RM, DeLong MR, Whitehouse PJ, Price DL. Primary dystonias: a review of the pathology and suggestions for new directions of study. Adv Neurol. 1988; 50:123-132. [PubMed: 3041757]

Hewett J, Gonzalez-Agosti C, Slater D, Ziefer P, Li S, Bergeron D, Jacoby DJ, Ozelius LJ, Ramesh V, Breakefield XO. Mutant torsinA, responsible for early-onset torsion dystonia, forms membrane inclusions in cultured neural cells. Hum Mol Genet. 2000; 9:1403-1413. [PubMed: 10814722]

Hewett J, Ziefer P, Bergeron D, Naismith T, Boston H, Slater D, Wilbur J, Schuback D, Kamm C, Smith N, Camp S, Ozelius LJ, Ramesh V, Hanson PI, Breakefield XO. TorsinA in PC12 cells: localization in the endoplasmic reticulum and response to stress. J. Neurosci Res. 2003; 72(2): 158-68. [PubMed: 12671990] 
Hewett J, Johanson P, Sharma N, Standaert DG, Balcioglu A. Function of dopamine transporter is compromised in DYT1 transgenic animal model in vivo. J Neurochem. 2010; 113:228-235. [PubMed: 20132487]

Hewett JW, Nery FC, Niland B, Ge P, Tan P, Hadwiger P, Tannous BA, Sah DW, Breakefield XO. siRNA knock-down of mutant torsinA restores processing through secretory pathway in DYT1 dystonia cells. Hum Mol Genet. 2008; 17:1436-1445. [PubMed: 18258738]

Hewett JW, Tannous B, Niland BP, Nery FC, Breakefield XO. Mutant torsinA interferes with protein processing through the secretory pathway in DYT1 dystonia cells. Proc Natl Acad Sci U S A. 2007; 104:7271-7276. [PubMed: 17428918]

Houlden H, Schneider SA, Paudel R, Melchers A, Schwingenschuh P, Edwards M, Hardy J, Bhatia KP. THAP1 mutations (DYT6) are an additional cause of early-onset dystonia. Neurology. 2010; 74:846-850. [PubMed: 20211909]

Huang X, Hutchins B, Patel RC. The C-terminal, third conserved motif of the protein activator PACT plays an essential role in the activation of double-stranded-RNA-dependent protein kinase (PKR). Biochem J. 2002; 366:175-186. [PubMed: 11985496]

Ichinose H, Ohye T, Takahashi E, Seki N, Hori T, Segawa M, Nomura Y, Endo K, Tanaka H, Tsuji S. Hereditary progressive dystonia with marked diurnal fluctuation caused by mutations in the GTP cyclohydrolase I gene. Nat Genet. 1994; 8:236-242. [PubMed: 7874165]

Jankovic J. Treatment of dystonia. Lancet Neurol. 2006; 5(10):864-72. [PubMed: 16987733]

Jossé L, Smales CM, Tuite MF. Transient expression of human TorsinA enhances secretion of two functionally distinct proteins in cultured Chinese hamster ovary $(\mathrm{CHO})$ cells. Biotechnol Bioeng. 2010; 105:556-566. [PubMed: 19845036]

Kabakci K, Hedrich K, Leung JC, Mitterer M, Vieregge P, Lencer R, Hagenah J, Garrels J, Witt K, Klostermann F, Svetel M, Friedman J, Kostic V, Bressman SB, Breakefield XO, Ozelius LJ, Pramstaller PP, Klein C. Mutations in DYT1: extension of the phenotypic and mutational spectrum. Neurology. 2004; 62:395-400. [PubMed: 14872019]

Kaiser FJ, Osmanovic A, Rakovic A, Erogullari A, Uflacker N, Braunholz D, Lohnau T, Orolicki S, Albrecht M, Gillessen-Kaesbach G, Klein C, Lohmann K. The dystonia gene DYT1 is repressed by the transcription factor THAP1 (DYT6). Ann Neurol. 2010; 68(4):554-9. [PubMed: 20976771]

Kalverda B, Pickersgill H, Shloma VV, Fornerod M. Nucleoporins directly stimulate expression of developmental and cell-cycle genes inside the nucleoplasm. Cell. 2010; 140:360-371. [PubMed: 20144760]

Katzenschlager R, Lees AJ. Treatment of Parkinson's disease: levodopa as the first choice. J Neurol. 2002; 249:119-124.

Kim CE, Perez A, Perkins G, Ellisman MH, Dauer WT. A molecular mechanism underlying the neural-specific defect in torsinA mutant mice. Proc Natl Acad Sci U S A. 2010; 107:9861-9866. [PubMed: 20457914]

Knappskog PM, Flatmark T, Mallet J, Ludecke B, Bartholome K. Recessively inherited L-DOPAresponsive dystonia caused by a point mutation $(\mathrm{Q} 381 \mathrm{~K})$ in the tyrosine hydroxylase gene. Hum Mol Genet. 1995; 4:1209-1212. [PubMed: 8528210]

Kock N, Naismith TV, Boston HE, Ozelius LJ, Corey DP, Breakefield XO, Hanson PI. Effects of genetic variations in the dystonia protein torsinA: identification of polymorphism at residue 216 as protein modifier. Hum Mol Genet. 2006; 15:1355-1364. [PubMed: 16537570]

Köhler A, Hurt E. Gene regulation by nucleoporins and links to cancer. Mol Cell. 2010; 38:6-15. [PubMed: 20385085]

Kuner R, Teismann P, Trutzel A, Naim J, Richter A, Schmidt N, von Ahsen O, Bach A, Ferger B, Schneider A. TorsinA protects against oxidative stress in COS-1 and PC12 cells. Neurosci. Lett. 2003; 350(3):153-6. [PubMed: 14550917]

Kustedjo K, Bracey MH, Cravatt BF. TorsinA and its torsion dystonia-associated mutant forms are lumenal glycoproteins that exhibit distinct subcellular localizations. J Biol Chem. 2000; 275:680685.

Kustedjo K, Deechongkit S, Kelly JW, Cravatt BF. Recombinant expression, purification, and comparative characterization of torsin A and its torsion dystonia-associated variant Delta EtorsinA. Biochemistry. 2003; 42:15333-15341. [PubMed: 14690443] 
Lee TG, Tang N, Thompson S, Miller J, Katze MG. The 58,000-dalton cellular inhibitor of the interferon-induced double-stranded RNA-activated protein kinase (PKR) is a member of the tetratricopeptide repeat 1994family of proteins. Mol Cell Biol. 1994; 14:23331-22342.

Lee ES, Yoon CH, Kim YS, Bae YS. The double-strand RNA-dependent protein kinase PKR plays a significant role in a sustained ER stress-induced apoptosis. FEBS J. 2007; 581:4325-4332.

Leung JC, Klein C, Friedman J, Vieregge P, Jacobs H, Doheny D, Kamm C, DeLeon D, Pramstaller PP, Penney JB, Eisengart M, Jankovic J, Gasser T, Bressman SB, Corey DP, Kramer P, Brin MF, Ozelius LJ, Breakefield XO. Novel mutation in the TOR1A (DYT1) gene in atypical early onset dystonia and polymorphisms in dystonia and early onset parkinsonism. Neurogenetics. 2001; 3:133-143. [PubMed: 11523564]

Macfarlan T, Kutney S, Altman B, Montross R, Yu J, Chakravarti D. Human THAP7 is a chromatinassociated, histone tail-binding protein that represses transcription via recruitment of HDAC3 and nuclear hormone receptor corepressor. J Biol Chem. 2005; 280:7346-7358. [PubMed: 15561719]

Macfarlan T, Parker JB, Nagata K, Chakravarti D. Thanatos-associated protein 7 associates with template activating factor-Ibeta and inhibits histone acetylation to repress transcription. Mol Endocrinol. 2006; 20:335-347. [PubMed: 16195249]

Martin JN, Bair TB, Bode N, Dauer WT, Gonzalez-Alegre P. Transcriptional and proteomic profiling in a cellular model of DYT1 dystonia. Neuroscience. 2009; 164:563-572. [PubMed: 19665049]

Mazars R, Gonzalez-de-Peredo A, Cayrol C, Lavigne AC, Vogel JL, Ortega N, Lacroix C, Gautier V, Huet G, Ray A, Monsarrat B, Kristie TM, Girard JP. The THAP-zinc finger protein THAP1 associates with coactivator HCF-1 and O-GlcNAc transferase: a link between DYT6 and DYT3 dystonias. J Biol Chem. 2010; 285:13364-13371. [PubMed: 20200153]

McLatchie LM, Fraser NJ, Main MJ, Wise A, Brown J, Thompson N, Solari R, Lee MG, Foord SM. RAMPs regulate the transport and ligand specificity of the calcitonin-receptor-like receptor. Nature. 1998; 393:333-339. [PubMed: 9620797]

Misbahuddin A, Placzek MR, Chaudhuri KR, Wood NW, Bhatia KP, Warner TT. A polymorphism in the dopamine receptor DRD5 is associated with blepharospasm. Neurology. 2002; 58:124-126. [PubMed: 11781417]

Misbahuddin A, Placzek MR, Taanman JW, Gschmeissner S, Schiavo G, Cooper JM, Warner TT. Mutant torsinA, which causes early-onset primary torsion dystonia, is redistributed to membranous structures enriched in vesicular monoamine transporter in cultured human SHSY5Y cells. Mov Disord. 2005; 20:432-440. [PubMed: 15593317]

Missale C, Nash SR, Robinson SW, Jaber M, Caron MG. Dopamine receptors: from structure to function. Physiol Rev. 1998; 78:189-225. [PubMed: 9457173]

Müller U. The monogenic primary dystonias. Brain. 2009; 132:2005-2025. [PubMed: 19578124]

Naismith TV, Heuser JE, Breakefield XO, Hanson PI. TorsinA in the nuclear envelope. Proc Natl Acad Sci U S A. 2004; 101:7612-7617. [PubMed: 15136718]

Naismith TV, Dalal S, Hanson PI. Interaction of torsinA with its major binding partners is impaired by the dystonia-associated DeltaGAG deletion. J Biol Chem. 2009; 284:27866-27874. [PubMed: 19651773]

Napolitano F, Pasqualetti M, Usiello A, Santini E, Pacini G, Sciamanna G, Errico F, Tassone A, Di Dato V, Martella G, Cuomo D, Fisone G, Bernardi G, Mandolesi G, Mercuri NB, Standaert DG, Pisan i. A. Dopamine D2 receptor dysfunction is rescued by adenosine A2A receptor antagonism in a model of DYT1 dystonia. Neurobiol Dis. 2010; 38:434-445. [PubMed: 20227500]

Naumann M, Pirker W, Reiners K, Lange KW, Becker G, Brucke T. Imaging the pre- and postsynaptic side of striatal dopaminergic synapses in idiopathic cervical dystonia: a SPECT study using [123I] epidepride and [123I] beta-CIT. Mov Disord. 1998; 13:319-323. [PubMed: 9539347]

Naviaux RK. Mitochondrial DNA disorders. Eur. J. Pediatr. 2000; 159(Suppl 3):S219-26. [PubMed: 11216904]

Nery FC, Zeng J, Niland BP, Hewett J, Irimia D, Li Y, Wiche G, Sonnenberg A, Breakefield XO. TorsinA participates in linkage between nuclear envelope and cytoskeleton. J Biol Cell. 2008; 121:3476-3486. 
O'Farrell CA, Martin KL, Hutton M, Delatycki MB, Cookson MR, Lockhart PJ. Mutant torsinA interacts with tyrosine hydroxylase in cultured cells. Neuroscience. 2009; 164:1127-1137. [PubMed: 19761814]

Ozelius LJ, Hewett JW, Page CE, Bressman SB, Kramer PL, Shalish C, de Leon D, Brin MF, Raymond D, Corey DP, Fahn S, Risch NJ, Buckler AJ, Gusella JF, Breakefield XO. The earlyonset torsion dystonia gene (DYT1) encodes an ATP-binding protein. Nat Genet. 1997; 17:4048. [PubMed: 9288096]

Page ME, Bao L, Andre P, Pelta-Heller J, Sluzas E, Gonzalez-Alegre P, Bogush A, Khan LE, Iacovitti L, Rice ME, Ehrlich ME. Cell-autonomous alteration of dopaminergic transmission by wild type and mutant (DeltaE) TorsinA in transgenic mice. Neurobiol Dis. 2010 Epub ahead of print.

Paisán-Ruiz C, Ruiz-Martinez J, Ruibal M, Mok KY, Indakoetxea B, Gorostidi A, Massó JF. Identification of a novel THAP1 mutation at R29 amino-acid residue in sporadic patients with early-onset dystonia. Mov Disord. 2009; 24:2428-2429. [PubMed: 19908320]

Park SK, Nguyen MD, Fischer A, Luke MP, Affar B, Dieffenbach PB, Tseng HC, Shi Y, Tsai LH. Par-4 links dopamine signaling and depression. Cell. 2005; 122:275-287. [PubMed: 16051151]

Paschen W, Frandsen A. Endoplasmic reticulum dysfunction--a common denominator for cell injury in acute and degenerative diseases of the brain? J. Neurochem. 2001; 79(4):719-25. [PubMed: 11723164]

Patel RC, Sen GC. PACT, a protein activator of the interferon-induced protein kinase, PKR. EMBO J. 1998; 17:4379-4390. [PubMed: 9687506]

Patel CV, Handy I, Goldsmith T, Patel RC. PACT, a stress-modulated cellular activator of interferoninduced double-stranded RNA-activated protein kinase, PKR. J Biol Chem. 2000; 275:3799337998. [PubMed: 10988289]

Perlmutter JS, Stambuk MK, Markham J, Black KJ, McGee-Minnich L, Jankovic J, Moerlein SM. Decreased $[18 \mathrm{~F}]$ spiperone binding in putamen in idiopathic focal dystonia. J Neurosci. 1997; 17:843-850. [PubMed: 8987805]

Peters GA, Dickerman B, Sen GC. Biochemical analysis of PKR activation by PACT. Biochemistry. 2009; 48:7441-7447. [PubMed: 19580324]

Peters GA, Hartmann R, Qin J, Sen GC. Modular structure of PACT: distinct domains for binding and activating PKR. Mol Cell Biol. 2001; 21:1908-1920. [PubMed: 11238927]

Pinninti NR, Mago R, Adityanjee J. Tardive dystonia-associated prescription of aripiprazole. Neuropsychiatry Clin Neurosci. 2006; 18:426-427.

Pisani A, Martella G, Tscherter A, Bonsi P, Sharma N, Bernardi G, Standaert DG. Altered responses to dopaminergic D2 receptor activation and $\mathrm{N}$-type calcium currents in striatal cholinergic interneurons in a mouse model of DYT1 dystonia. Neurobiol Dis. 2006; 24:318-325. [PubMed: 16934985]

Placzek MR, Misbahuddin A, Chaudhuri KR, Wood NW, Bhatia KP, Warner TT. Cervical dystonia is associated with a polymorphism in the dopamine (D5) receptor gene. J Neurol Neurosurg Psychiatry. 2001; 71:262-264. [PubMed: 11459908]

Quartarone A, Rizzo V, Morgante F. Clinical features of dystonia: a pathophysiological revisitation. Curr Opin Neurol. 2008; 21:484-490. [PubMed: 18607211]

Raven JF, Koromilas AE. PERK and PKR: old kinases learn new tricks. Cell Cycle. 2008; 7:11461150. [PubMed: 18418049]

Rostasy K, Augood SJ, Hewett JW, Leung JC, Sasaki H, Ozelius LJ, Ramesh V, Standaert DG, Breakefield XO, Hedreen JC. TorsinA protein and neuropathology in early onset generalized dystonia with GAG deletion. Neurobiol Dis. 2003; 12:11-24. [PubMed: 12609485]

Roussigne M, Cayrol C, Clouaire T, Amalric F, Girard JP. THAP1 is a nuclear proapoptotic factor that links prostate-apoptosis-response-4 (Par-4) to PML nuclear bodies. Oncogene. 2003a; 22:24322442. [PubMed: 12717420]

Roussigne M, Kossida S, Lavigne AC, Clouaire T, Ecochard V, Glories A, Amalric F, Girard JP. The THAP domain: a novel protein motif with similarity to the DNA-binding domain of P element transposase. Trends Biochem Sci. 2003b; 28:66-69. [PubMed: 12575992] 
Sabogal A, Lyubimov AY, Corn JE, Berger JM, Rio DC. THAP proteins target specific DNA sites through bipartite recognition of adjacent major and minor grooves. Nat Struct Mol Biol. 2010; 17:117-123. [PubMed: 20010837]

Sciamanna G, Bonsi P, Tassone A, Cuomo D, Tscherter A, Viscomi MT, Martella G, Sharma N, Bernardi G, Standaert DG, Pisani A. Impaired striatal D2 receptor function leads to enhanced GABA transmission in a mouse model of DYT1 dystonia. Neurobiol Dis. 2009; 34:133-145. [PubMed: 19187797]

Segawa M. Hereditary progressive dystonia with marked diurnal fluctuation. Brain Dev. 2000; 1:S6580. [PubMed: 10984664]

Seibler P, Djarmati A, Langpap B, Hagenah J, Schmidt A, Brüggemann N, Siebner H, Jabusch HC, Altenmüller E, Münchau A, Lohmann K, Klein C. A heterozygous frameshift mutation in PRKRA (DYT16) associated with generalised dystonia in a German patient. Lancet Neurol. 2008; 7:380-381. [PubMed: 18420150]

Sells SF, Han SS, Muthukkumar S, Maddiwar N, Johnstone R, Boghaert E, Gillis D, Liu G, Nair P, Monnig S, Collini P, Mattson MP, Sukhatme VP, Zimmer SG, Wood DPJ, McRoberts JW, Shi Y, Rangnekar VM. Expression and function of the leucine zipper protein Par-4 in apoptosis. Mol Cell Biol. 1997; 17:3823-3832. [PubMed: 9199316]

Sharma N, Baxter MG, Petravicz J, Bragg CD, Schienda A, Standaert DG, Breakefield XO. Impaired motor learning in mice expressing torsinA with the DYT1 dystonia mutation. J Neurosci. 2005; 25:5351-5355. [PubMed: 15930383]

Shashidharan P, Paris N, Sandu D, Karthikeyan L, McNaught KS, Walker RH, Olanow CW. Overexpression of torsinA in PC12 cells protects against toxicity. J. Neurochem. 2004; 88(4): 1019-25. [PubMed: 14756824]

Shashidharan P, Sandu D, Potla U, Armata IA, Walker RH, McNaught KS, Weisz D, Sreenath T, Brin MF, Olanow CW. Transgenic mouse model of early-onset DYT1 dystonia. Hum Mol Genet. 2005; 14:125-133. [PubMed: 15548549]

Snapp EL, Hegde RS, Francolini M, Lombardo F, Colombo S, Pedrazzini E, Borgese N, LippincottSchwartz J. Formation of stacked ER cisternae by low affinity protein interactions. J Cell Biol. 2003; 163:257-269. [PubMed: 14581454]

Tamiya G. Transcriptional dysregulation: a cause of dystonia? Lancet Neurol. 2009; 8:416-418. [PubMed: 19345149]

Tanabe LM, Kim CE, Alagem N, Dauer WT. Primary dystonia: molecules and mechanisms. Nat Rev Neurol. 2009; 5:598-609. [PubMed: 19826400]

Tolosa E, Compta Y. Dystonia in Parkinson's disease. J Neurol. 2006; (Suppl 7):VII7-13. [PubMed: 17131231]

Torres GE, Sweeney AL, Beaulieu JM, Shashidharan P, Caron MG. Effect of torsinA on membrane proteins reveals a loss of function and a dominant-negative phenotype of the dystonia-associated DeltaE-torsinA mutant. Proc Natl Acad Sci U S A. 2004; 101:15650-15655. [PubMed: 15505207]

Torvinen M, Torri C, Tombesi A, Marcellino D, Watson S, Lluis C, Franco R, Fuxe K, Agnati LF. Trafficking of adenosine A2A and dopamine D2 receptors. J Mol Neurosci. 2005; 25:191-200. [PubMed: 15784967]

Wagner ML, Fedak MN, Sage JI, Mark MH. Complicatioins of disease and therapy: a comparison of younger and older patients with Parkinson's disease. Ann Clin Lab Sci. 1996; 26:389-395. [PubMed: 8879356]

Walter M, Bonin M, Pullman RS, Valente EM, Loi M, Gambarin M, Raymond D, Tinazzi M, Kamm C, Glockle N, Poths S, Gasser T, Bressman SB, Klein C, Ozelius LJ, Riess O, Grundmann K. Expression profiling in peripheral blood reveals signature for penetrance in DYT1 dystonia. Neurobiol. Dis. 2010; 38(2):192-200. [PubMed: 20053375]

Wichmann T. Commentary: Dopaminergic dysfunction in DYT1 dystonia. Exp Neurol. 2008; 212:242-246. [PubMed: 18513716]

Wider C, Melquist S, Hauf M, Solida A, Cobb SA, Kachergus JM, Gass J, Coon KD, Baker M, Cannon A, Stephan DA, Schorderet DF, Ghika J, Burkhard PR, Kapatos G, Hutton M, Farrer MJ, 
Wszolek ZK, Vingerhoets FJ. Study of a Swiss dopa-responsive dystonia family with a deletion in GCH1: redefining DYT14 as DYT5. Neurology. 2008; 70:1377-1383. [PubMed: 17804835]

Xiao J, Zhao Y, Bastian RW, Perlmutter JS, Racette BA, Tabbal SD, Karimi M, Paniello RC, Wszolek ZK, Uitti RJ, Van Gerpen JA, Simon DK, Tarsy D, Hedera P, Truong DD, Frei KP, Dev Batish S, Blitzer A, Pfeiffer RF, Gong S, LeDoux MS. Novel THAP1 sequence variants in primary dystonia. Neurology. 2010; 74:229-238. [PubMed: 20083799]

Zhao Y, Decuypere M, Ledoux MS. Abnormal motor function and dopamine neurotransmission in DYT1 DeltaGAG transgenic mice. Exp Neurol. 2008; 210:719-730. [PubMed: 18299128]

Zhu CY, Li CY, Li Y, Zhan YQ, Li YH, Xu CW, Xu WX, Sun HB, Yang XM. Cell growth suppression by thanatos-associated protein 11(THAP11) is mediated by transcriptional downregulation of c-Myc. Cell Death Differ. 2009; 18:395-405. [PubMed: 19008924]

Zhu L, Millen L, Mendoza JL, Thomas PJ. A unique redox-sensing sensor-II motif in TorsinA plays a critical role in nucleotide and partner binding. J Biol Chem. Sep 22.2010 2010 Epub ahead of print.

Zirn B, Grundmann K, Huppke P, Puthenparampil J, Wolburg H, Riess O, Muller U. Novel TOR1A mutation p.Arg288Gln in early-onset dystonia (DYT 1). J Neurol Neurosurg Psychiatry. 2008 
A

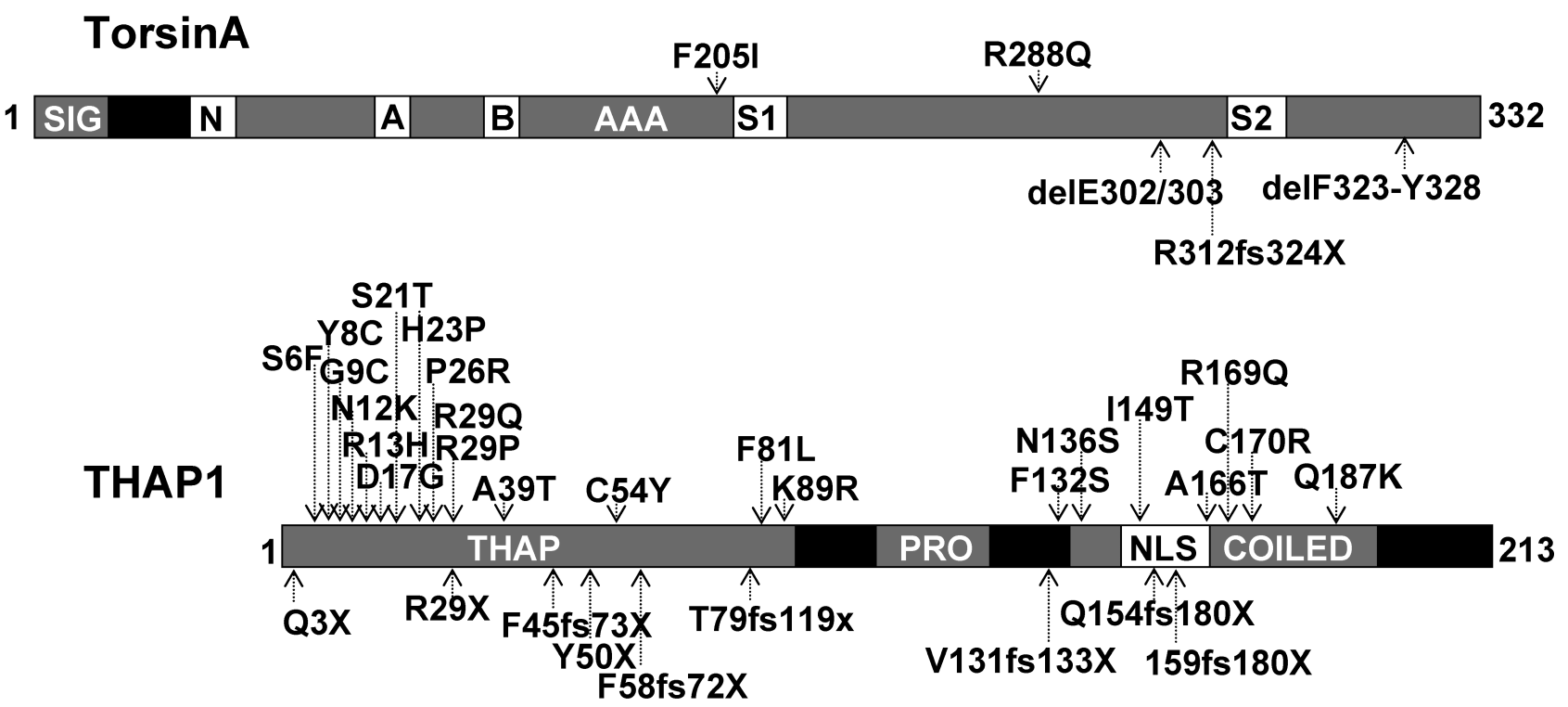

\section{PACT}

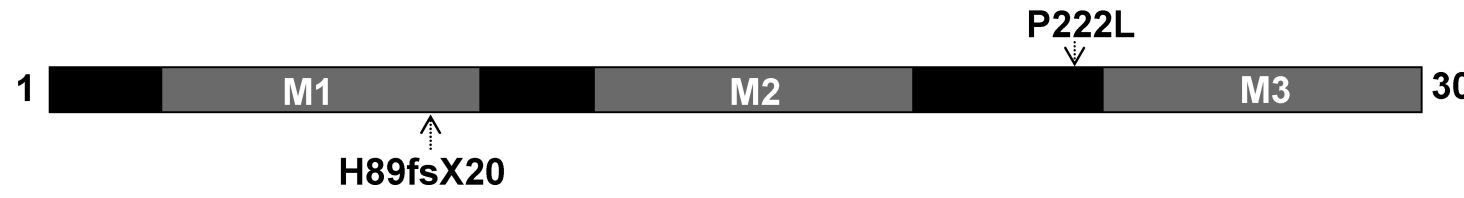

Figure 1. Proteins encoded by DYT1, DYT6, and DYT16 genes

Schematics of the three proteins are shown with dystonia-related mutations indicated relative to functional domains. Missense mutations are shown above each protein's sequence, while deletions/truncating mutations are shown below. (A) The DYT1 protein, torsin $\mathrm{A}$, is a member of the $\mathrm{AAA}^{+}$superfamily of molecular chaperones. Key functional motifs include: an N-terminal signal sequence (SIG), N-linker $(\mathrm{N})$ at the boundary of the $\mathrm{AAA}^{+}$cassette (AAA), Walker A (A) and B (B) domains, and sensor 1 (S1) and 2 (S2) characteristic of members of this protein family. Five known mutations are shown, of which only one, delE302/303 has been clearly established as pathogenic. (B) The DYT6 protein, THAP1, is a zinc-finger protein consisting of a conserved DNA binding module (THAP), a central proline-rich region (PRO), and a coiled-coil domain (COILED) which includes a nuclear localization signal (NLS). Most mutations are predicted to disrupt key residues in either the DNA binding region or the NLS. (C) The DYT16 protein, PACT, regulates activity of protein kinase R, through three modular domains (M1-3). Domains M1 and M2 are involved in kinase binding while M3 is required for activation. The P222L mutation falls near the boundary of M3, while the frameshift mutation occurs in M1 and may potentially truncate the protein. 


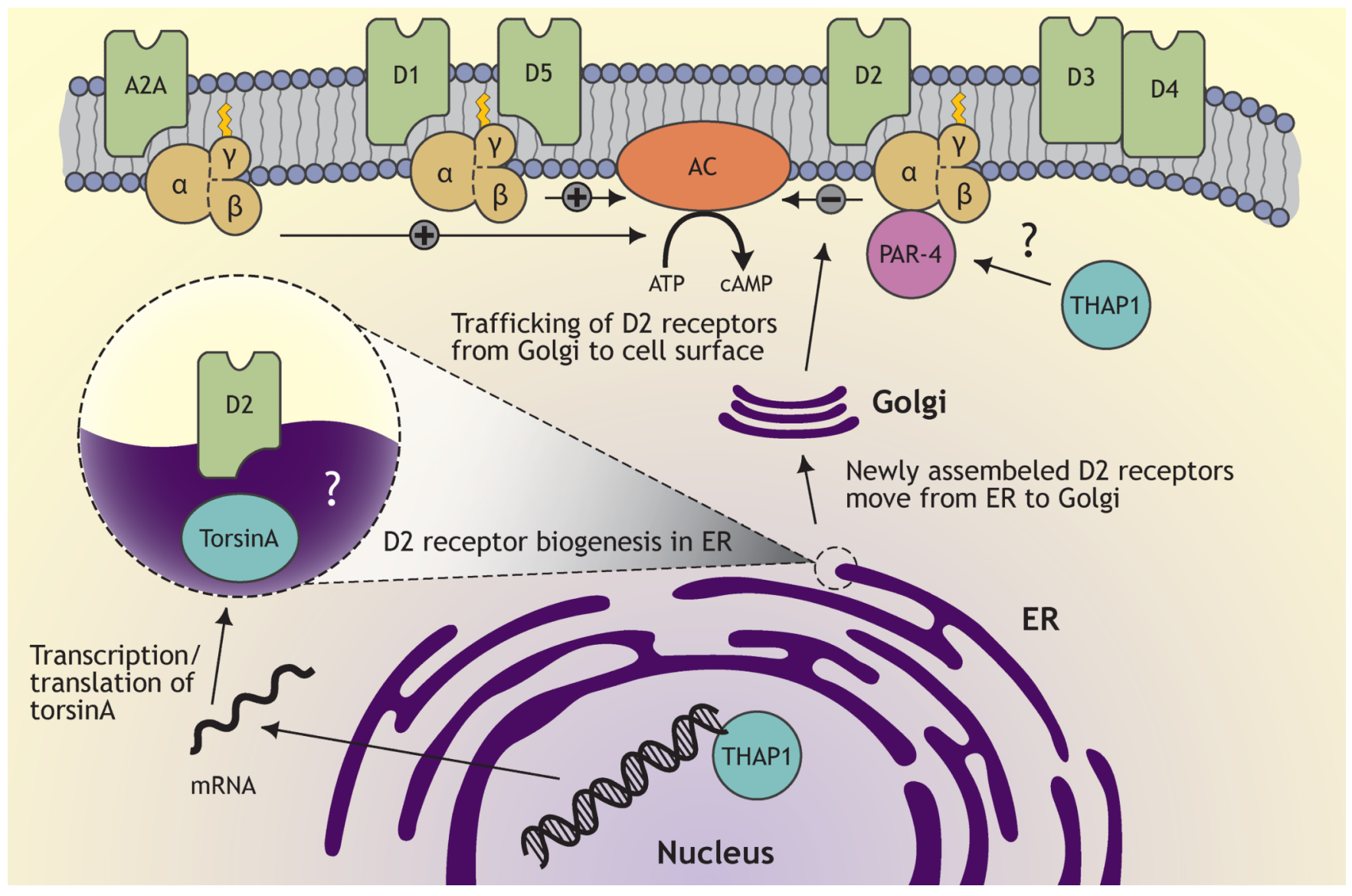

Figure 2. Potential interactions between torsinA, THAP1, and components of dopaminergic neurotransmission

Dopamine (DA) receptors can be classified into 5 subtypes, D1-D5, all of which signal through heterotrimeric G-proteins that act on adenylate cyclase (AC). Activation of D1 and $\mathrm{D} 5$ receptors stimulates $\mathrm{AC}$ to increase $\mathrm{AMP}$ production, while $\mathrm{D} 2$ receptor activation inhibits AC and decreases cAMP levels. D3 and D4 are thought to function similarly to D2 receptors. Trafficking of DA receptors to the cell surface begins in the ER and depends on molecular chaperones. Given that DYT1 patients and mouse models both show decreased D2 receptor availability at the cell surface, it is possible that torsinA participates in the processing of $\mathrm{D} 2$ receptors in the ER and that the mutant form, torsin $\mathrm{A} \Delta \mathrm{E}$, loses this ablity, producing a trafficking defect. THAP1 interacts directly with Par-4, which competes with calmodulin for binding to a cytosolic regulatory site on the D2 receptor. A loss of Par-4 results in increased binding by calmodulin and a decrease in D2 activity. It is not known whether and how DYT6 mutations in THAP1 affect Par-4 and its interaction with D2. THAP1 has been recently shown to negatively regulate torsinA expression. DYT6 mutations in THAP1 which lose this activity could potentially result in increased torsinA levels, which in turn could create imbalances in the ER which also perturb chaperone activity. The predicted net effect of a D2 defect is a loss of inhibitory input to AC which results in aberrant cAMP-related signaling during DA neurotransmission. Antagonists of adenosine A2A receptors could potentially compensate for decreased D2 activity and normalize transmission. 


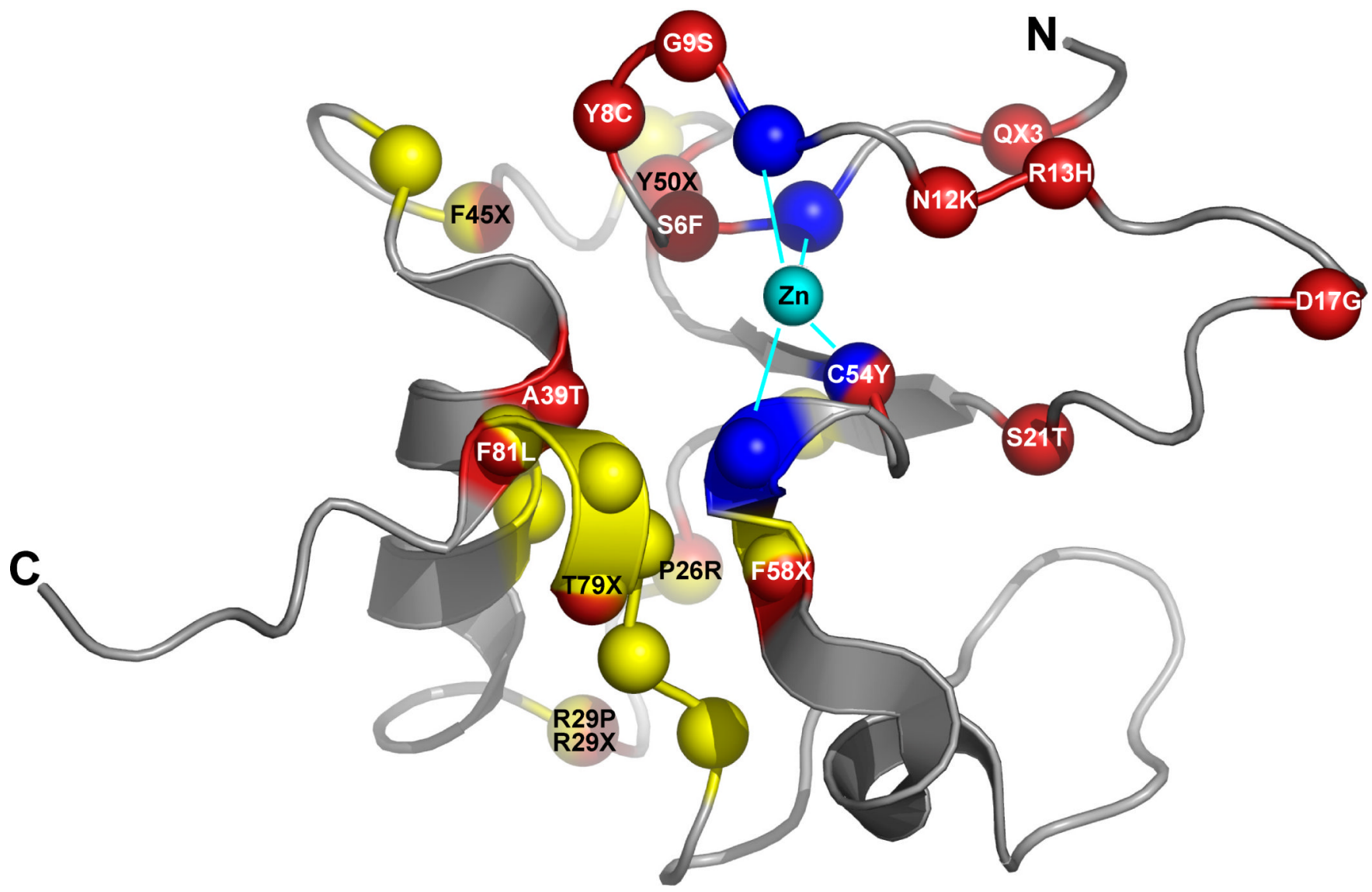

Figure 3. DYT6 mutations in DNA binding module of THAP1

NMR solution structure of THAP1's DNA binding domain as determined by Bessiere et al., (2008). Positions are highlighted to indicate: (a) four zinc coordinating residues (dark blue) with zinc ion (light blue); (b) residues which, when individually mutated, were shown to significantly decrease or even abolish DNA binding (yellow); and (c) known DYT6 mutants (red). 


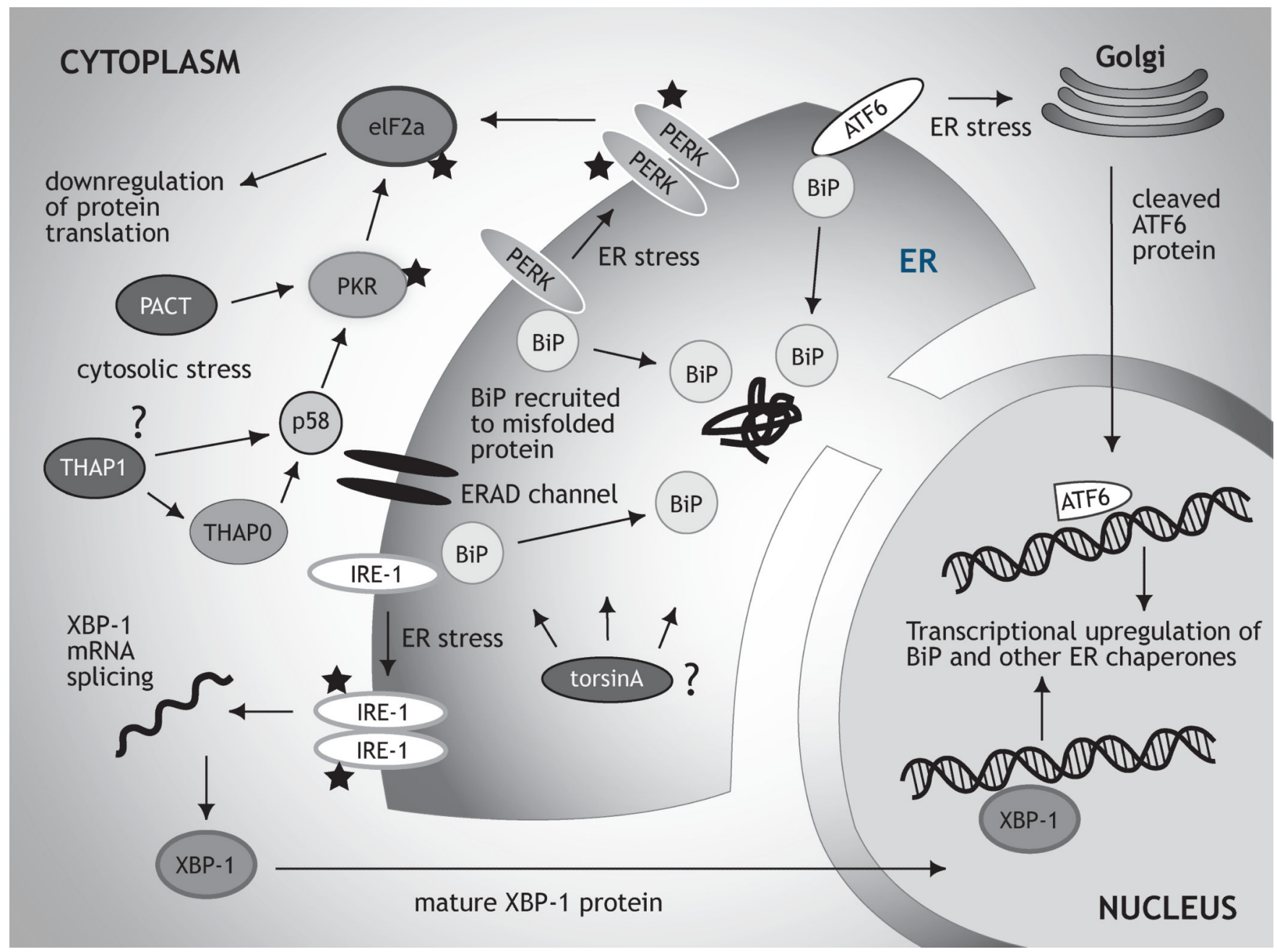

Figure 4. Potential interactions between torsinA, PACT, and THAP proteins in endoplasmic reticulum stress signaling

Components of the unfolded protein response (UPR). The UPR chaperone, BiP, is recruited to misfolded proteins, resulting in activation of three key ER stress mediators, IRE-1, ATF6, and PERK. Activated IRE-1 results in splicing of the mRNA encoding XBP-1, producing a mature transcription factor that translocates to the nucleus and upregulates expression of molecular chaperones. Activated ATF6 is transported to the Golgi, where it is cleaved to produce a mature transcription factor that also upregulates chaperone expression. Activated PERK phosphorylates eIF2a, which transiently decreases global protein synthesis to ease the burden in the ER. TorsinA is believed to function at some level in this cascade, while torsin $\mathrm{A} \triangle \mathrm{E}$ may impair the cell's ability to respond to misfolded proteins. PACT responds to cytosolic and ER stresses to activate PKR, which also phosphorylates eiF2a to decrease protein synthesis. Mutations in PACT which prevent PKR activation would also impair the cell's ability to respond to ER and other stress stimuli. PKR is normally inhibited by p58IPK (p58), although this inhibition is removed during stress signaling by THAP0, a close relative of THAP1. It is not yet known whether THAP1 itself participates directly in the p58IPK/ PKR pathway. 

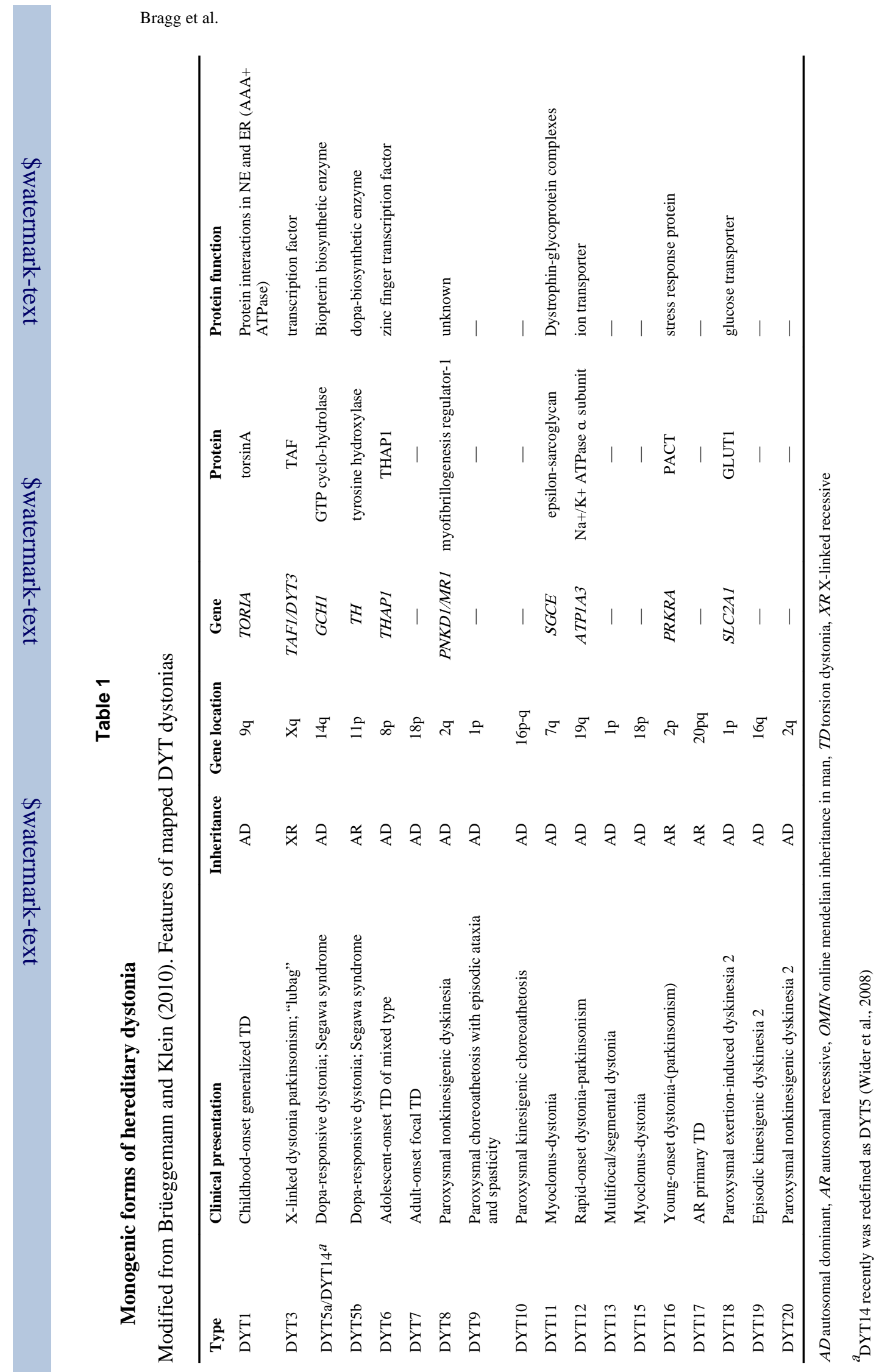

Neurobiol Dis. Author manuscript; available in PMC 2012 May 01. 